\title{
Contemporary Modes of Corrosion Protection and Functionalization of Materials
}

\author{
Ingrid Milošev ${ }^{*}$ \\ Jožef Stefan Institute, Department of Physical and Organic Chemistry, Jamova c. 39, SI-1000, Ljubljana, Slovenia \\ *Corresponding author: E-mail: ingrid.milosev@ijs.si, URL: http://www.ijs.si/ijsw/K3-en/Milosev, \\ https://orcid.org/0000-0002-7633-9954, Google Scolar Ingrid Milosev \\ Tel: +386-1-477-34-52; Fax: +386-1-251-93-85
}

Received: 04-02-2019

Paper presented as key-note lecture at the $24^{\text {th }}$ Annual Meeting of the Slovenian Chemical Society,

Portorož, 19. - 21. 9. 2018

\begin{abstract}
Corrosion protection is an important global issue. Corrosion affects all metal materials in industry, infrastructure, civil engineering, transport, biomedicine, etc. causing their deterioration and degradation. Corrosion protection is a necessity which enables the safe and well-functioning of metal structures and devices. In addition to long-term efficiency, corrosion protection should be environmentally and economically acceptable. Growing population with needs on modern and high-tech technologies is boosting consumption of base and rare earth metals. All these issues are putting high demands on area of corrosion protection with the main goal to prolong the life-time of metal materials, reduce the need for steeply increasing production and thus preserve resources. In this review contemporary modes of corrosion protection of metal materials with the emphasis on copper and aluminium base alloys as one of most important base metals are presented. These include corrosion inhibitors, conversion, sol-gel and hydrophobic coatings. Examples are our research studies over the last decade are presented.
\end{abstract}

Keywords: Corrosion; corrosion protection; inhibitors; conversion coatings; sol-gel coatings; hydrophobic coatings

\section{Introduction}

\section{1. Corrosion and Related Costs}

Corrosion is a degradation of a material (usually a metal) due to its reaction with environment. It is a naturally occurring phenomenon of a material that results from a chemical or electrochemical reaction with its environment. ${ }^{1}$ Majority of corrosion processes are electrochemical in nature as the electron transfer is involved. The occurrence of corrosion is dependent on number of factors including inherent material properties like composition and microstructure and environmental conditions such as corrosiveness of medium, temperature, stress, load, etc. (Fig. 1).

Corrosion takes place on the metal surface where heterogeneous sites exist (anodic and cathodic sites). These sites are present at the same metal specimen due to heterogeneity of the surface related to metal impurities, microstructure, grain orientation, local composition, etc. At anodic sites reaction of metal dissolution takes place, while at cathodic sites the reduction of oxygen or protons

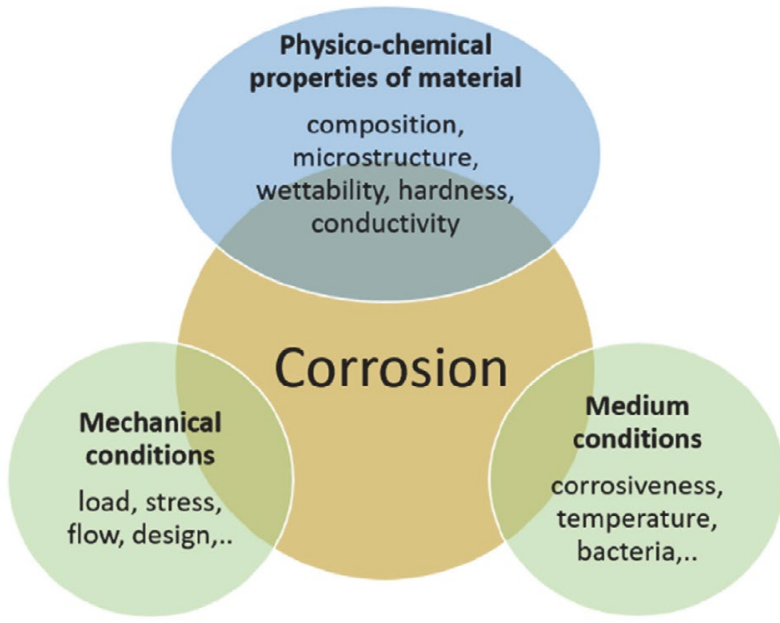

Figure 1. Factors influencing corrosion process of metal materials.

in electrolyte occurs. Two basic modes of corrosion processes can be distinguished: uniform corrosion which pro- 
ceeds uniformly at the whole surface, and localized corrosion which is limited to certain sites at the surfaces; these are usually sites insufficiently protected by the protective layer. Localized corrosion processes are for example pitting, crevice and intergranular corrosion and dealloying (Fig. 2).

Almost all metals and alloys are prior exposure subjected to some type of corrosion protection aiming to prolong the life-time under operating conditions. ${ }^{1,2}$ Environmental conditions to which metals and alloys are exposed to are versatile and comprise urban and industrial atmospheres, marine and soil environments, elevated temperature, load or pressure, etc. Materials are consequently often subjected to very harsh conditions containing corrosive species like chloride or sulphide ions. Corrosion protection is therefore a required procedure which enables the industrial sector, infrastructure, transportation, etc. and our daily life to operate under optimal conditions and to maintain a high level of functional performance. Last but not least, well protected surfaces assure a safe performance of a structure or device. Let us not forget that serious accidents can happen due to loss of structure integrity of devices, vehicles, or infrastructures like bridges or cable cars. ${ }^{3}$ including automobiles, railways, airplanes, etc. (ca. 24\%), energy including coal mining, fossil fuel power, oil and gas industry, etc. (ca. 20\%), infrastructure including roads, bridges, etc. (ca. $7 \%)$ and water including water supply and drainage (ca. 1\%). ${ }^{5}$ When taking into consideration direct costs in five major anti-corrosion measures the largest share accounts for coatings (ca. 66\%), corrosion-resistant materials (ca. 19\%), surface treatments (ca. 13\%), electrochemical protection (ca. 0.6\%), corrosion inhibitors (ca. $0.5 \%)$ and rust preventing oils and greases (ca. $0.2 \%) .{ }^{5}$

\section{2. Copper and Aluminium Alloys as Important Technological Materials}

Copper and aluminium together with iron, zinc and lead belong to so called base metals which are utilized in everyday life. Precious metals are gold, silver and platinum, while rare earth metals like neodymium, dysprosium, samarium, etc. are becoming increasing important due to high-tech industries. Global demand for base metals such as iron, copper and aluminium, is rising steeply in $21^{\text {st }}$ century. ${ }^{6,7,8,9,10}$ This trend is the result of increasing global population, economic growth in large and highly

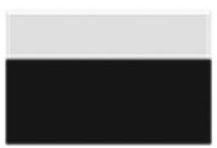

No corrosion

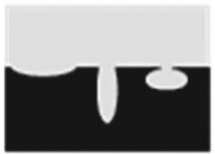

Pitting
Uniform

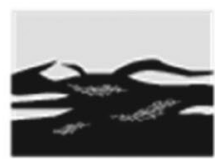

Exfoliation

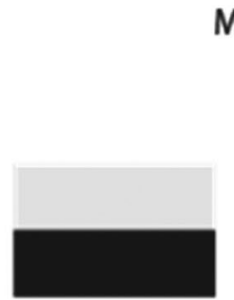

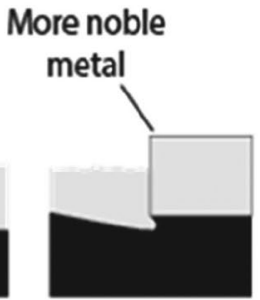

Galvanic
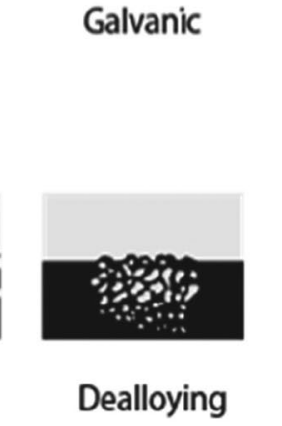

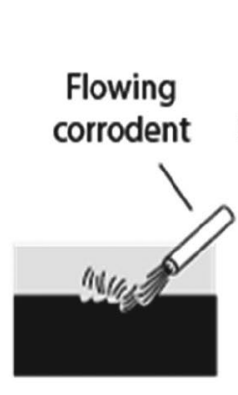

Erosion

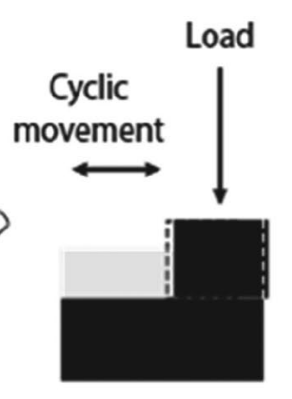

Fretting

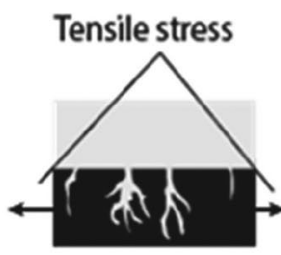

Intergranular
Kini

Hर

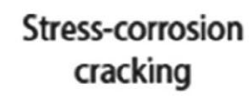

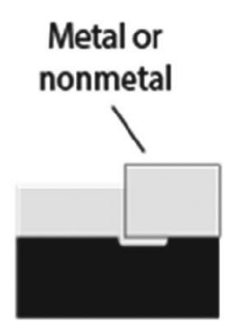

Crevice

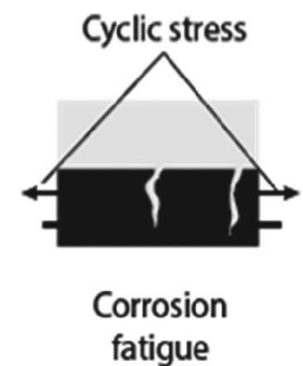

Figure 2. Different modes of corrosion processes

Annual costs due to corrosion amount to over 300 billion USD in USA and over 310 billion USD in China, representing about $3.3 \%$ of the gross domestic product. ${ }^{1,4,5}$ When taking into consideration direct corrosion costs in five major economic sectors the highest costs are associated with manufacturing and public services including chemical industry, electronics, agriculture production and cultural heritage (ca. 48\%), following by transportation populated countries, and the transition to a more sustainable society due to increase of copper- and aluminium-intensive low-carbon energy and electrification of transport technologies. ${ }^{9,10}$ Annual production of aluminium was estimated to approximately 63.2 million tonnes in 2017 with a $5.8 \%$ increase compared to year before. ${ }^{8}$ Annual mine production of copper was estimated to approximately 21 million tonnes in $2018 .{ }^{11}$ A $50 \%$ increase is expected 
in 10 years, even up to $350 \%$ by $2050 .{ }^{9,10}$ Considering these data it is reasonable to conclude that an efficient corrosion protection of base metal resources is a necessity.

This paper will focus on $\mathrm{Cu}$ - and $\mathrm{Al}$ alloys. Although copper plays an important role in modern society, it was used already by the ancient Egyptians. Today, copper tubes comprise ca. $90 \%$ of European and North American hot and cold water supplies. ${ }^{12}$ Copper exhibits good mechanical properties such as hardness, strength and ductility; it has the best electrical conductivity and good thermal conductivity. These properties are the basis for applications of copper alloys in heat transfer, e.g. for heat exchangers, radiators, power distribution systems, etc. Copper is chemically relatively inert and when exposed to the atmosphere, protective layers of oxides and poorly soluble salts are formed on the surface. Copper alloys are suitable for marine environments, as well as for outdoor housing constructions, sculptures and statues, etc. Copper can be readily joined, e.g. by brazing and soldering. It is also suitable for recycling. Copper alloys can be divided in several families (Fig. 3) based on their composition: brasses and manganese bronze (Cu-Zn, Cu-Zn-Mg), bronze (Cu-Sn, $\mathrm{Cu}-\mathrm{Al}, \mathrm{Cu}-\mathrm{Si}$ ) copper-nickels $(\mathrm{Cu}-\mathrm{Ni})$, nickel-silver alloys $(\mathrm{Cu}-\mathrm{Ni}-\mathrm{Zn})$, gunmetals ( $\mathrm{Cu}-\mathrm{Sn}-\mathrm{Zn}-\mathrm{Pb})$ and copper-beryllium alloys (Cu-Be). According to temper, copper alloys are classified as annealed (A), manufactured (M), cold-worked $(\mathrm{H})$, heat-treated (T), quench-hardened (Q), etc. ${ }^{13}$ Areas of applications of various aluminium alloys are denoted in Fig. relatively good corrosion resistance, as well as their appearance and low cost (current price of $\mathrm{Al}$ ca. 1,900 USD/tonne and for $\mathrm{Cu} c a$. 6,300 USD/tonne ${ }^{14}$ ). These materials are used in a variety of applications, especially in aircraft, architecture, automotive and marine industries. ${ }^{16}$ Alloying aluminium results in improved mechanical properties but also in a heterogeneous microstructure containing numerous intermetallic particles (IMPs). Due to strong galvanic coupling between IMPs and the aluminium matrix, exposure of aluminium alloys to aqueous solutions containing chlorides leads to localised corrosion. ${ }^{17}$ Eight types of wrought aluminium alloys are designed depending on the major alloying element (Fig. 3): $1 x x x$ (unalloyed), $2 x x x$ with copper, $3 x x x$ with manganese, $4 x x x$ with silicon, $5 x x x$ with magnesium, $6 x x x$ with magnesium and silicon, $7 x x x$ with zinc as major alloying element, and $8 x x x$ with other major elements. Alloys are divided into heat-treatable $(2 x x x, 6 x x x$ and $7 x x x)$ and non-heat treatable (1xxx,3xxx,4xxx and $5 x x x)$. Aluminium alloys are designated with four digits $(x \times x x)$ : the first digit indicates the principal alloying element, the second digit, if different from 0 , indicates a modification of the specific alloy, and the third and fourth digits are arbitrary numbers given to identify a specific alloy in the series. Basic temper designations include letters $F$ (as fabricated), O (annealed), H (strain hardened), W (solution heat-treated) and T (thermally treated). ${ }^{17}$ Areas of applications of various aluminium alloys are denoted in Fig. 3. Aluminium alloys are suitable material for recycling.

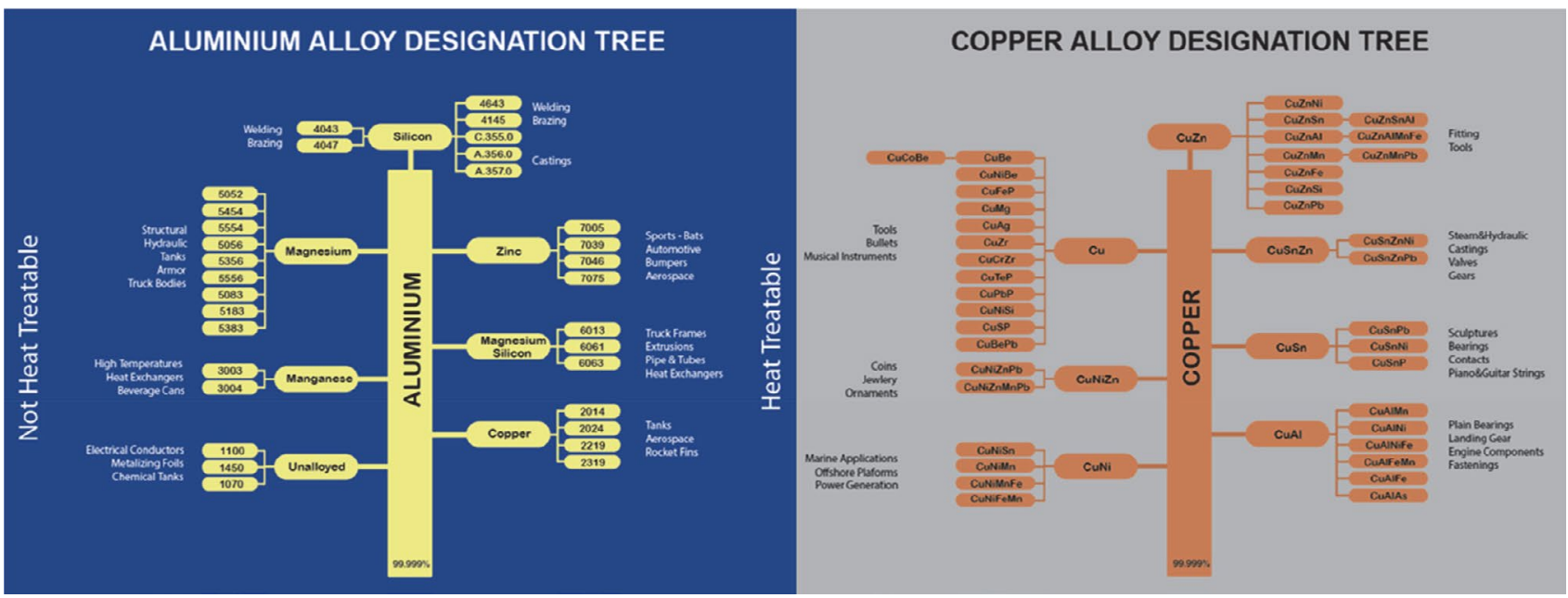

Figure 3. Families of aluminium and copper alloys (modified from ref. 15 and ref. 12).

3. Copper alloys develop attractive colours - from red of copper, the gold of brasses and aluminium bronzes, the chocolate-brown of manganese bronzes, the green patina and shiny white nickel-silver. ${ }^{12}$ The exploitation of copper alloys is therefore very attractive also for decorative purposes due to advantage of their inherent range of colours.

Aluminium and aluminium alloys are used widely due to their favourable mechanical properties, low density,

\section{3. Corrosion Protection and Current State- of-the-art}

First step to corrosion protection is a proper selection of material (or surface treatment) and engineering of a well-designed device or structure. Many problems can be avoided by adequately selected materials and designs for specific applications. In general, corrosion protection in- 
cludes (i) modification of electrolyte metal is exposed to by inhibitors, (ii) use of various surface treatments or coatings, or (iii) change of the potential by achieving cathodic protection (sacrificial anodes or impressed current) or anodic protection (maintaining of stable passive film). ${ }^{1,2}$ In this review, former two approaches will be treated, i.e. corrosion inhibitors and coatings.

Copper and copper alloys are extremely resistant to corrosion, but subjected to superficial discolouring tarnish which can be avoided by applying thin clear protective coatings to their surfaces. There are hundreds of useful clear coating products on the market, formulated from numerous polymers, solvents, and additives. ${ }^{18}$ Although the palette of colours of copper alloys is broad, in some applications may be desirable to change the colour, most commonly using brown or statuary finishes for bronze and green or patina finishes for copper. ${ }^{18}$ Contemporary pre-treatments specifically for aluminium alloys are chemical conversion coatings - chromate- or chromium(III)-based, zirconium- and titanium-based, and anodization. ${ }^{19,20,21,22}$ Finishing procedure is usually phosphating or electrophoretic paint (electro-coating). ${ }^{23}$

In past, the most important conversion coatings used for corrosion protection of ferrous and non-ferrous metal substrates are chromate conversion coatings (CCCs) and phosphate coatings. These treatments were invented approximately 100 years ago $^{24}$ and they have been used in large-scale commercial applications over the last 60-70 years. ${ }^{25}$ Chromate conversion coatings (CCCs) were first developed in 1915 by Bauer and Vogel ${ }^{24}$ by treating aluminium for $2 \mathrm{~h}$ at $90{ }^{\circ} \mathrm{C}$ in a solution of potassium carbonate, sodium bicarbonate and potassium dichromate. The method was modified and then patented in 1923 (modified Bauer Vogel, MBV process) including immersion in $\mathrm{Na}_{2} \mathrm{CO}_{3}$ and $\mathrm{Na}_{2} \mathrm{Cr}_{2} \mathrm{O}_{7}$ for 5-10 min. Over the years, the process has been further modified but all CCC baths use chromate compounds. CCCs are highly corrosion protective. They consist of a backbone of chromium oxide/hydroxide with $\mathrm{Cr}$ in the $3+$ oxidation state and also contain compounds with $\mathrm{Cr}$ in the $6+$ oxidation state. ${ }^{26,27}$ The $\mathrm{Cr}(\mathrm{VI})$ provides the characteristic of self-healing, which is the ability to reform a protective coating after it has been breached by a mechanical or chemical process. It proceeds by the reduction of remaining $\mathrm{Cr}(\mathrm{VI})$ in the coating to an insoluble $\mathrm{Cr}^{3+}$ compound. The phosphating process, on the other hand, was patented in 1943 with the introduction of Jernstadt salt (disodium phosphate containing titanium), which developed into zinc phosphate coatings. Phosphate coatings are hard, continuous, insoluble and electrically non-conducting and are used in numerous applications in the automotive, agriculture and appliance industries. ${ }^{28}$

Chromate compounds are toxic and carcinogenic and thus unacceptable for contact by humans and contamination of the environment. The use of hexavalent chromium is restricted in the European Union and the USA. ${ }^{29,30}$ In European Union is restricted by the Restriction of Hazard- ous Substances (RoHS) Directive 2002/95/EC (EU RoHS 1), which took effect in 2006 and was replaced by the Directive EU RoHS 2 in $2011 .{ }^{29}$ Both directives restrict the use of certain hazardous substances in electrical and electronic equipment (hexavalent chromium is limited to a maximum concentration value of $0.1 \%$ by weight). The use of hexavalent chromium is further restricted by the European Chemical Agency (ECHA) $)^{31}$ and the related REACH ${ }^{31}$ (Registration, Evaluation, Authorization and Restriction of Chemicals) regulation. Hexavalent chromium belongs to the SVHC (Substances of Very High Concern) list which cannot be placed on the market or used after a given date ("sunset date"), unless the authorization is granted for their specific use, or the use is exempted from authorization. Most recent sunset date for chromium(VI) compounds was January 2019. ${ }^{31}$ Applications for authorisation have been prepared by some industrial consortia, e.g. aerospace, for the use of some chromates, i.e. chromium trioxide.

Problems related to phosphate coatings are associated impact of phosphate discharge on groundwater sources due to eutrophication in fresh water lakes and reservoirs caused by phosphorus. Environmental regulations therefore restrict the use of phosphorus. ${ }^{32}$ Operating temperature of phosphating baths is typically about $50^{\circ} \mathrm{C}$, which requires energy input. Furthermore, production of phosphate coatings is related to the formation of a sludge containing metal ions, which necessitates frequent desludging to maintain optimum bath operation.

As a result of these issues, both chromium and phosphate conversion coatings are being increasingly replaced and alternatives are being continuously sought. In this review, various modes of corrosion protection of copperand aluminium-alloys-inhibitors, conversion coatings, sol-gel coatings, hydrophobic coatings-are presented aiming to retrospect our own investigations in this exciting field of research which is becoming increasingly important for the society as a whole. Different modes of preparation of protective layers or coatings on metal surface are schematically presented in Fig. 4 .

$\mathrm{NaCl}$ solution is taken as a model corrosive electrolyte (usually concentrations of $0.1 \mathrm{M}, 0.5 \mathrm{M}$ or $3.5 \mathrm{wt} . \%$ are used). Inhibitors can be either added directly to $\mathrm{NaCl}$ followed by electrochemical measurements in the same solution, or inhibitor layers can be pre-formed by immersion of metal sample in ethanol solution of inhibitor (or other solvent where inhibitor is soluble) followed by measurements in $\mathrm{NaCl}$. The same principle is valid for conversion coatings - either rare earth salt is added directly to $\mathrm{NaCl}$ and then immersed for a certain period of time a conversion to occur, or conversion layer can be pre-formed in solution of rare earth salt, usually with hydrogen peroxide added to stimulate the conversion, followed by measurements in $\mathrm{NaCl}$. Sol-gel and hydrophobic coatings are always pre-deposited prior measurements in $\mathrm{NaCl}$ using dipping, spinning or spraying. These coatings act as barrier protection. When inhibitor is added to sol-gel or hydro- 


\section{Inhibitors}

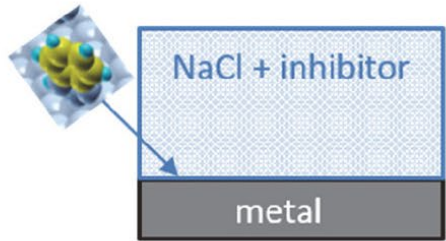

DIRECT IMMERSION

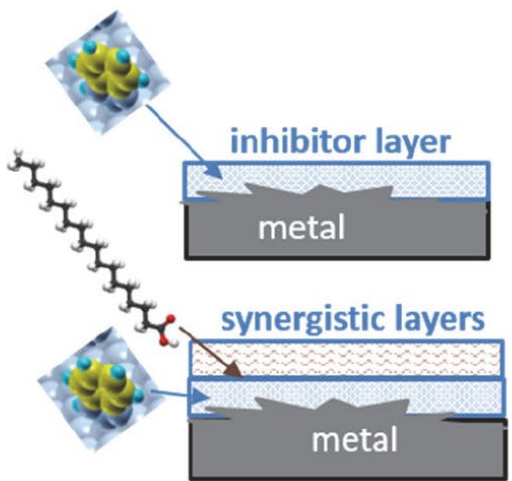

PRE-PREPARATION

\section{Conversion coatings}
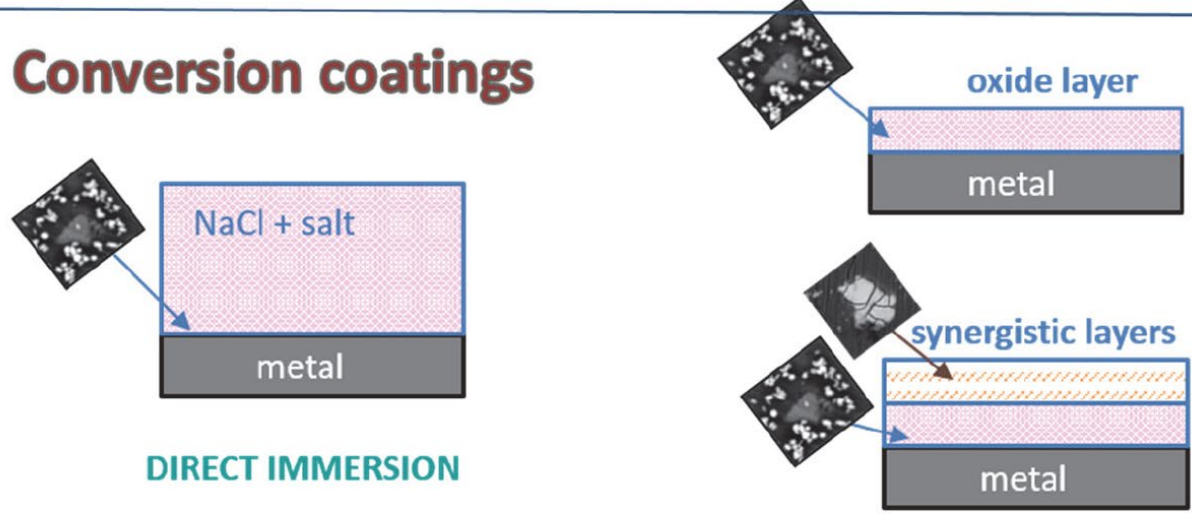

PRE-PREPARATION

\section{Sol-gel coatings}

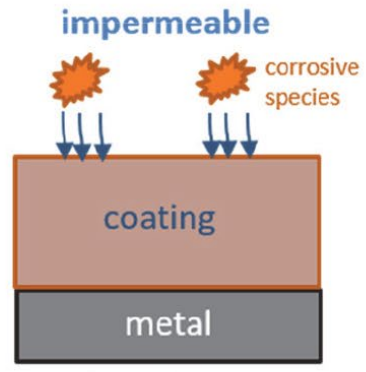

BARRIER PROTECTION

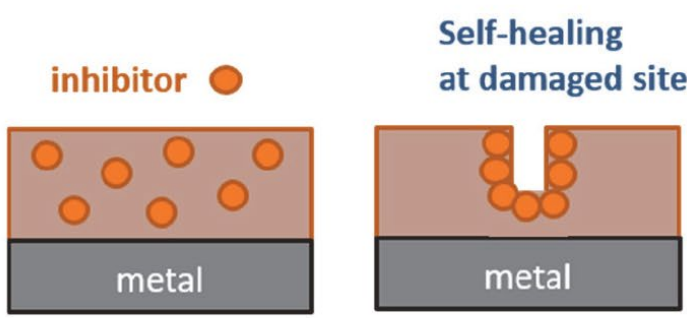

ACTIVE PROTECTION

\section{Hydrophobic coatings}

hydro/superhydrophobic

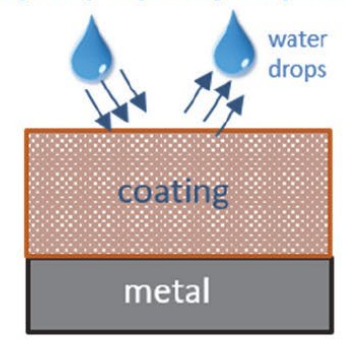

BARRIER PROTECTION

Figure 4. Modifications of metal surfaces using various strategies.

phobic coating to gain the active protection, artificially made scribe is made to simulate the corrosion damage and then self-healing of damaged site is followed by electrochemical or non-electrochemical methods.

\section{Corrosion Inhibitors}

The inhibition of corrosion using corrosion inhibitors has been for decades one of the most important method of corrosion protection. Inhibitors are inorganic or organic compounds which when added in small concentra- tions form a surface layer that protects the underlying metal surface from dissolution and, consequently, decreases the corrosion rate. The choice of inhibitors is based on its inhibition efficiency but also on price and environmental harmlessness.

Inhibitors can be basically divided to (i) environmental conditioners (scavengers) and (ii) interface inhibitors. ${ }^{1}$ (i) Scavengers decrease corrosivity of the medium by removing aggressive species, e.g. addition of hydrazine reduces the oxygen content and consequently the rate of cathodic reaction. (ii) Interface inhibitors can be divided to liquid- and vapour-phase inhibitors. 
Liquid-based inhibitors can be classified as anodic, cathodic and mixed depending on whether they mainly affect anodic, cathodic or both reactions, respectively. ${ }^{1}$ The mechanism of inhibition is usually based on adsorption of inhibitors on the metal surface and formation of a protective layer. Anodic inhibitors are thus commonly referred as passivating inhibitors such as chromate, nitrite, molybdate, etc. resulting in the formation of sparingly soluble oxide, hydroxides or salts. These inhibitors are most efficient and widely used. Due to chromate toxicity, however, seek for alternatives is of a priority. Cathodic inhibitors can be classified as (i) so called cathodic poisons and (ii) cathodic precipitators. (i) Cathodic poisons form adsorbed (sulphides, selenides) metallic layers (As, $\mathrm{Bi}, \mathrm{Sb}$ ), or protective layers (silicates, phosphates, borates) and decrease the rate of cathodic reaction by limiting the diffusion of oxygen to metal surface. (ii) Precipitators precipitate at selective sites at the surface to form insoluble compounds (Ca, $\mathrm{Zn}$, or Mg carbonates). Mixed inhibitors affect both anodic and cathodic reaction and can act through physisorption, chemisorption and film formation. ${ }^{1}$

Vapour-phase inhibitors are substances which slowly release chemical compounds within a sealed airspace that actively prevents surface corrosion, e.g. to protect stored tools or parts inside bags, boxes or cupboards. ${ }^{1}$

Electrochemical reactions on copper immersed in $\mathrm{NaCl}$ corrosion medium comprise the cathodic reaction of reduction of oxygen, reaction (1) and anodic reaction of copper electrodissolution, reactions (2)-(6). ${ }^{33,34}$ The mechanism of copper electrodissolution in chloride media has been widely investigated. ${ }^{35}$ It proceeds through direct dissolution of metal and formation of $\mathrm{CuCl}_{2}{ }^{-}$complex (reaction 2): ${ }^{35,36}$

$$
\begin{aligned}
& \mathrm{O}_{2}(\mathrm{aq})+2 \mathrm{H}_{2} \mathrm{O}+4 \mathrm{e}^{-} \rightarrow 4 \mathrm{OH}^{-}(\mathrm{aq}) \\
& \mathrm{Cu}+2 \mathrm{Cl}^{-} \rightleftharpoons \mathrm{CuCl}_{2}^{-}+\mathrm{e}^{-}
\end{aligned}
$$

or through intermediate formation of $\mathrm{CuCl}$ (reactions $3-4)$ :

$$
\begin{aligned}
& \mathrm{Cu}+\mathrm{Cl}^{-} \rightleftharpoons \mathrm{CuCl}+\mathrm{e}^{-} \\
& \mathrm{CuCl}+\mathrm{Cl}^{-} \rightleftharpoons \mathrm{CuCl}_{2}^{-}
\end{aligned}
$$

or through reaction between cuprous and chloride ions (reactions 5-6):

$$
\begin{aligned}
& \mathrm{Cu} \rightleftharpoons \mathrm{Cu}^{+}+\mathrm{e}^{-} \\
& \mathrm{Cu}^{+}+2 \mathrm{Cl}^{-} \rightleftharpoons \mathrm{CuCl}_{7}^{-}
\end{aligned}
$$

At potentials close to corrosion potential $\left(E_{\text {corr }}\right)$ the anodic reaction is under mixed charge transfer and mass transport control (rate of movement of cuprous chloride complex away from the surface to bulk electrolyte) (Fig. 5). ${ }^{37,38,39}$ At approximately $0.1 \mathrm{~V}$ the peak in current is at a minimum, indicating that the $\mathrm{CuCl}$ covers the surface. The $\mathrm{CuCl}$ layer is not protective and reacts further, forming the $\mathrm{CuCl}_{2}{ }^{-}$complex which is soluble in aqueous media and can either diffuse into the solution or can be further oxidized. This process takes place at potentials more positive than $0.1 \mathrm{~V}:{ }^{37}$

$$
\mathrm{CuCl}_{2(\mathrm{ads})}^{-} \rightleftharpoons \mathrm{Cu}^{2+}+2 \mathrm{Cl}^{-}+\mathrm{e}^{-}
$$

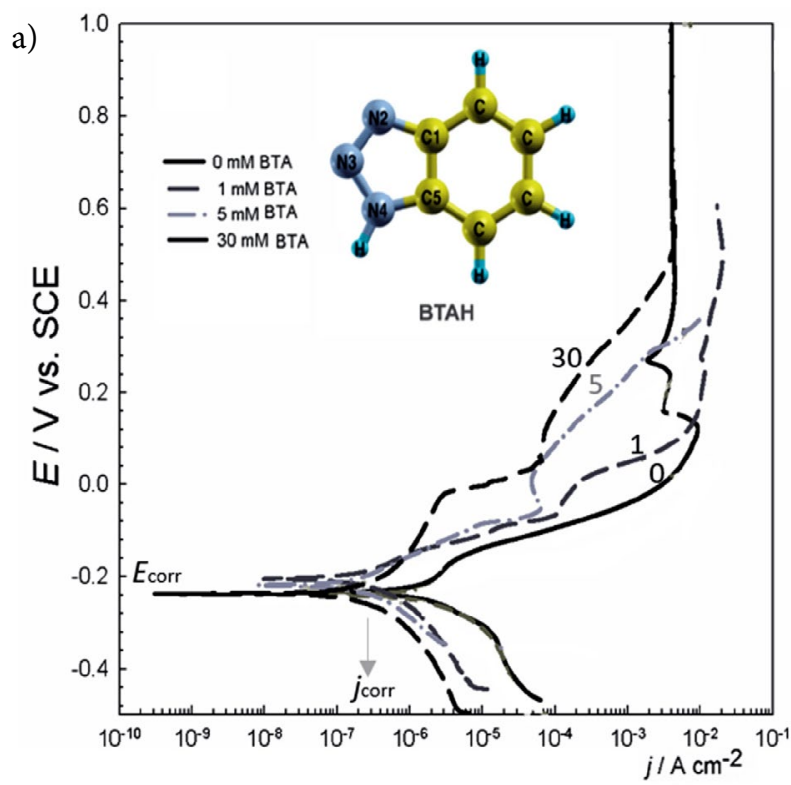

b)
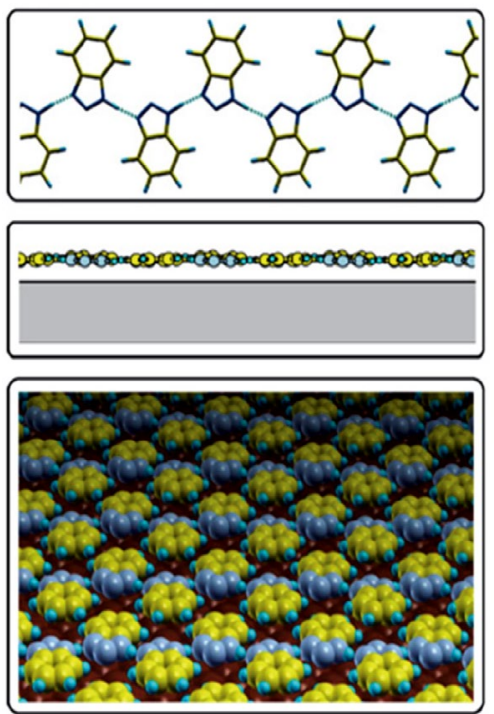

Figure 5. (a) Polarization curves recorded for copper in $0.5 \mathrm{M} \mathrm{NaCl}$ with and without benzotriazole (BTA) added in concentration of 1 , 5 and $30 \mathrm{mM}$. Scan rate was $1 \mathrm{mV} / \mathrm{s}$. (Reprinted from the publication by T. Kosec, I. Milošev, B. Pihlar, Appl. Surf. Sci., 2007, 253, 8863-8873 with permission from Elsevier. ${ }^{37}$ ) Skeletal structure of BTA is given in inset. (b) The structure of BTA is planar and therefore favourable for physisorption on metal surface as shown by tentative structure; planar physisorbed BTAH polymers are packed so as to form compact and thin film. (Reprinted from the publication by M. Finšgar, A. Lesar,A. Kokalj, I. Milošev, Electrochim. Acta, 2008, 53, 8287-8297 with permission from Elsevier. ${ }^{39}$ ) 
Among the most important inhibitors for copper are triazole and imidazole-based inhibitors. Benzotriazole (BTAH) has been known since 1947 to be a very effective inhibitor of corrosion for copper and copper alloys. ${ }^{40}$ $\mathrm{BTAH}$ is a heterocyclic organic compound with a molar mass of $119.124 \mathrm{~g} / \mathrm{mol}$; at room temperature is a whitish powder which is sufficiently soluble in water solutions. It is only slightly toxic so it does not constitute a major environmental hazard. ${ }^{40}$ The form of the molecule in aqueous solution depends on the $\mathrm{pH}$ and can be either neutral (BTAH), negatively charged $\left(\mathrm{BTA}^{-}\right)$or protonated $\left(\mathrm{BTAH}_{2}^{+}\right), 41, .40$

$$
\begin{aligned}
& \mathrm{BTAH}_{2}^{+} \rightleftharpoons \mathrm{BTAH}+\mathrm{H}^{+}, \mathrm{pK}_{1} \approx 1 \\
& \mathrm{BTAH} \rightleftharpoons \mathrm{BTA}^{-}+\mathrm{H}^{+}, \mathrm{pK}_{2} \approx 8.2
\end{aligned}
$$

In slightly acidic environments benzotriazole is present mainly in the undissociated form as BTAH, whilst at alkaline $\mathrm{pH}$ the molecule is predominantly present in the $\mathrm{BTA}^{-}$form. ${ }^{39} \mathrm{BTAH}$ is protonated at the N3-nitrogen atom in an acidic environment (Fig. 5). Protonation decreases $\pi$ orbital energy which leads to lower resonance energy and, in consequence, the interaction between benzotriazole and metal becomes weaker. ${ }^{40}$ Therefore, BTAH is less effective in an acidic environment. The instability of $\mathrm{Cu}$ oxides in acidic environments could further reduce the effectiveness of the copper surface protection. Moreover, the build-up of a polymerized network of $\mathrm{Cu}$-BTA chains is most strongly favored at an oxidized $\mathrm{Cu}$ surface, i.e. in solutions where copper oxide is stable. ${ }^{39}$

In $\mathrm{NaCl}$ solution containing BTAH above $0.05 \mathrm{mM}$, a barrier film is formed which causes the reduction of current density in both cathodic and, especially, anodic region, while the corrosion potential does not change significantly (Fig. 5). Therefore, BTAH acts primarily as anodic inhibitor that retards exodus of $\mathrm{Cu}$ ions, reaction (5), and, secondarily, as a cathodic inhibitor preventing oxygen reduction, reaction (1). The formation of barrier layer can be expressed as: ${ }^{40}$

$$
\begin{aligned}
& \mathrm{Cu}+\mathrm{BTAH} \rightarrow(\mathrm{Cu}-\mathrm{BTAH})_{\mathrm{ads}} \\
& n \mathrm{CuCl}_{2}^{-}+n \mathrm{BTAH}^{\top} \rightarrow(\mathrm{Cu}-\mathrm{BTAH})_{\mathrm{n}}+n \mathrm{H}^{+}+2 n \mathrm{Cl}^{-} \\
& (\mathrm{Cu}-\mathrm{BTAH})_{\mathrm{ads}}+(\mathrm{Cu}-\mathrm{BTAH})_{\mathrm{n}} \rightarrow[(\mathrm{Cu}-\mathrm{BTAH}) \\
& \left.-(\mathrm{Cu}-\mathrm{BTAH})_{\mathrm{n}}\right]_{(\mathrm{ads})}
\end{aligned}
$$

Barrier layer is a mixture of cuprous species and $\mathrm{Cu}(\mathrm{I})$-BTA complex forming a polymerized network. ${ }^{38}$ The thickness of the barrier layer formed in inhibitor-containing solution is much smaller than of that formed in chloride solution, i.e. $2.4 \mathrm{~nm}$ compared to $8.5 \mathrm{~nm}$, respectively. ${ }^{38}$ The film formed at near neutral $\mathrm{pH}$, where the stability of cuprous species is high, is very stable and dense. Density functional molecular electronic structure revealed that BTAH has the ability to for planar H-bonded poly-

\section{Triazole derivates}<smiles>c1c[nH]nn1</smiles>

1,2,3-triazole TAH<smiles>c1ccc2[nH]nnc2c1</smiles>

benzotriazole BTAH<smiles>On1nnc2ccccc21</smiles>

1-hydroxybenzotriazole BTAOH<smiles>c1ccc2cc3[nH]nnc3cc2c1</smiles>

naphthotriazole NTAH

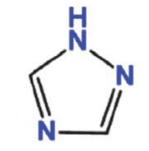

1,2,4-triazole TriH<smiles>Cn1cncn1</smiles>

1-methyl-1,2,4-triazole TriMe

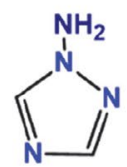

1-amino-1,2,4-triazole 1-ATriH<smiles>Nc1nc[nH]n1</smiles>

3-amino-1,2,4-triazole 3-ATriH

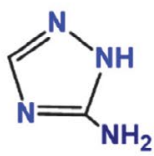

5-amino-1,2,4-triazole 5-ATriH

Imidazole derivates<smiles>c1c[nH]cn1</smiles>

imidazole ImiH

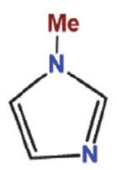

1-methyl-imidazole ImiMe<smiles>C1=CC=C2N=C(N=C1)N2</smiles>

benzimidazole BimH<smiles>Sc1nc2ccccc2[nH]1</smiles><smiles>Cn1c(S)nc2ccccc21</smiles>

2-mercaptobenzimidazole SH-BimH 2-mercapto-1-methylbenzimidazole SH-BimMe

Figure 6. Skeletal formulae of triazole and imidazole derivatives used as corrosion inhibitors. 


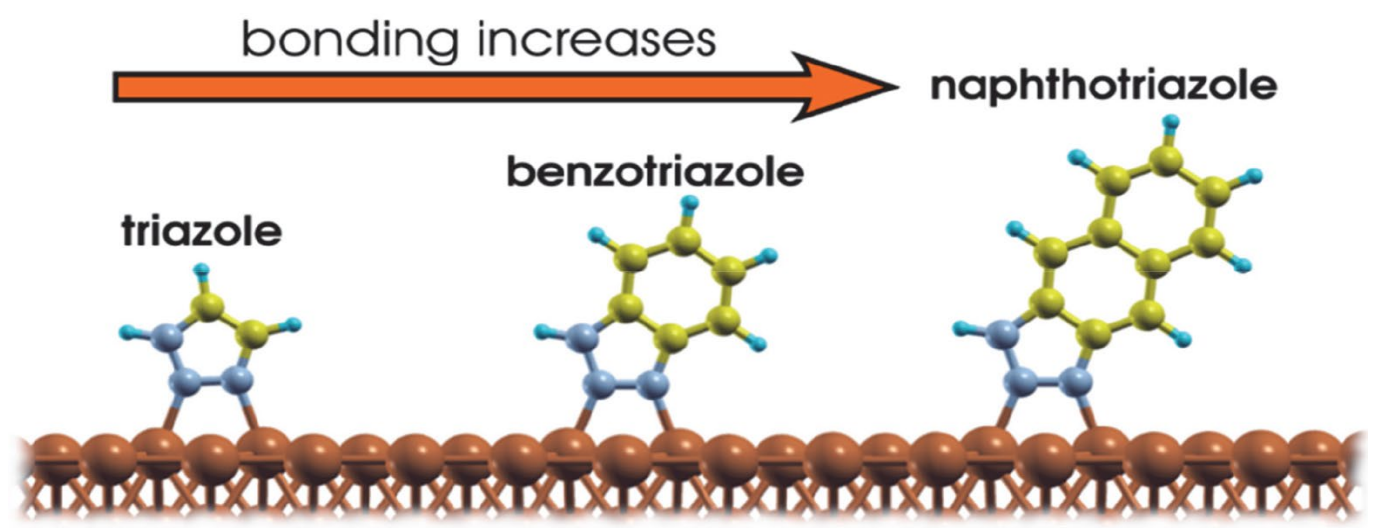

Figure 7. Optimized physisorption/chemisorption structures of triazole (TAH), benzotriazole (BTAH) and naphthotriazole (NTAH) on Cu surface. The bonding increases with molecular size from TAH to NTAH as calculated by density functional theory (DFT) calculations. (Reprinted from the publication by A. Kokalj, N. Kovačević, S. Peljhan, M. Finšgar, A. Lesar, I. Milošev, ChemPhysChem, 2011, 12, 3547-3555 with permission from John Wiley and Sons. ${ }^{47}$ )

mers of favourable geometry form physisorption. ${ }^{42}$ These can be packed on the surface and form a thin and compact layer (Fig. 5b). ${ }^{39}$ The interplay between molecular structure, adsorption (chemisorption and physisorption) and intramolecular bonding (e.g. H-bonding) is crucial for the formation of efficient inhibitors. ${ }^{42}$

Benzotriazole is efficient inhibitor for copper in chloride containing solution but also for brasses $(\mathrm{Cu}-\mathrm{xZn}$ alloys). ${ }^{37,38}$ Derivatives of BTAH are also considered as inhibitors for copper corrosion (Fig. 6). 1-hydroxybenzotriazole $(\mathrm{BTAOH})$ exhibits poorer inhibition efficiency compared to BTAH which was ascribed to its non-planar structure and inability to form thin polymer films. ${ }^{43,44}$ Amino derivatives of 1,2,4-triazole $\left(\mathrm{TriH}^{1}\right)$ were also considered:3-amino-1,2,4-triazole (3-ATriH), 5-amino-1,2,4-triazole (5-ATriH) and 1-amino-1,2,4-triazole (1-ATriH) (Fig. 6). 3-ATriH was shown to be the most effective inhibitor, the effectiveness decreasing in the order 3-ATriH $>5-\mathrm{ATriH}>1-\mathrm{ATriH}>\mathrm{TriH} .{ }^{45}$ Compared to $\mathrm{BTAH}$, however, shows A-TriH less efficient inhibition. ${ }^{46}$ Triazole derivatives with $\mathrm{NH}_{2}$ group bonded to either of the $\mathrm{C}$ atoms have stronger inhibition properties than those of 1,2,4-triazole or of that with the amino group bonded to ring $\mathrm{N}$ atom. ${ }^{45}$ Further, the molecular electronic and adsorption properties of 1,2,3-triazole (TAH), benzotriazole (BTAH) and naphthotriazole (NTAH) molecules were compared ${ }^{47}$ The molecule-surface bond strength increases with increasing the molecular size, thus following the TriHe < $\mathrm{BTAH}<\mathrm{NTAH}$ sequence (Fig. 7). ${ }^{47}$ The molecules chemisorbed in an upright geometry; molecular electronegativity and chemical hardness decrease monotonously as the molecular size increases. BTAH and NTAH can physisorb positioning the molecular plane almost parallel to the surface. However, although NTAH seems to be more efficient inhibitor than BTAH, high price limits its usage. ${ }^{47}$

In addition to triazoles, imidazole and its derivatives were investigated (Fig. 6). Imidazole (ImiH) is less effec-

1 1,2,4-triazole was denoted ATA in original publication. ${ }^{45}$ tive inhibitor than most of its derivatives, which was partly ascribed to its high solubility. ${ }^{48,49}$ The benzene, methyl and mercapto derivatives of imidazoles were investigated: benzimidazole (BimH), 1-methyl-imidazole (ImiMe), 2-mercapto-1-methyl-imidazole (SH- ImiMe) and 2-mercaptobenzimidazole (SH-BimH)) (Fig. 8a). ${ }^{48,49}$ The inhibition efficiency of these compounds, deduced from electrochemical measurements, differs markedly. At inhibitor concentration of $1 \mathrm{mM}$ the following trend was established: $\mathrm{SH}-\mathrm{BimH}>\mathrm{SH}-\mathrm{ImiMe}>\mathrm{BimiH}>\mathrm{ImiH}>\mathrm{ImiMe}$ (Fig. 8a). These inhibitors act as mixed inhibitors with a stronger effect on the anodic reaction, i.e. dissolution of copper, reaction (5). The mercapto group and benzene group are shown to have a beneficial effect on corrosion inhibition, whereas the effect of the methyl group is, interestingly, different: at lower concentrations ( 0.1 and $1 \mathrm{mM})$ the effect is only slightly disadvantageous, but at higher concentrations the disadvantageous effect is amplified and ImiMe even accelerates the corrosion at $10 \mathrm{mM} \cdot{ }^{48,50} \mathrm{After}$ one month's immersion in solution containing ImiH and ImiMe cupric compounds were detected; cupric complexes are soluble and ImiH and ImiMe are consequently poor inhibitors.

Another factors which has to be taken into account when considering efficiency of an inhibitor is the effect of inhibitor-substrate interactions: DFT calculations revealed that ImiMe, SH-ImiMe, BimH and SH-BimH inhibitors bind stronger to iron that to copper surfaces, but this has no direct relevance to corrosion inhibition. ${ }^{51}$ As iron is chemically more reactive to copper, in general it binds adsorbates stronger than copper. In contrast to copper, where mercapto containing derivatives of imidazoles were beneficial for all concentrations tested, their inhibition of iron corrosion was advantageous compared to other derivatives only at low concentration (Fig. 8b).$^{51}$ Furthermore, methyl-derivative of imidazole had a positive impact on inhibition of iron corrosion at all concentrations. Therefore, relative adsorption bonding strength of inhibitors com- 


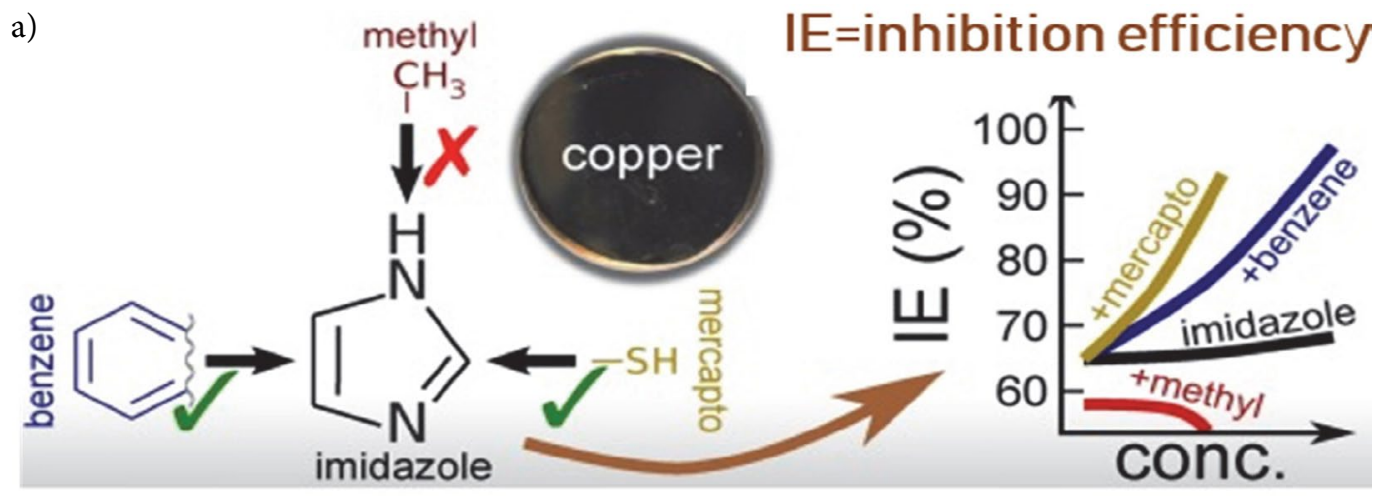

b)

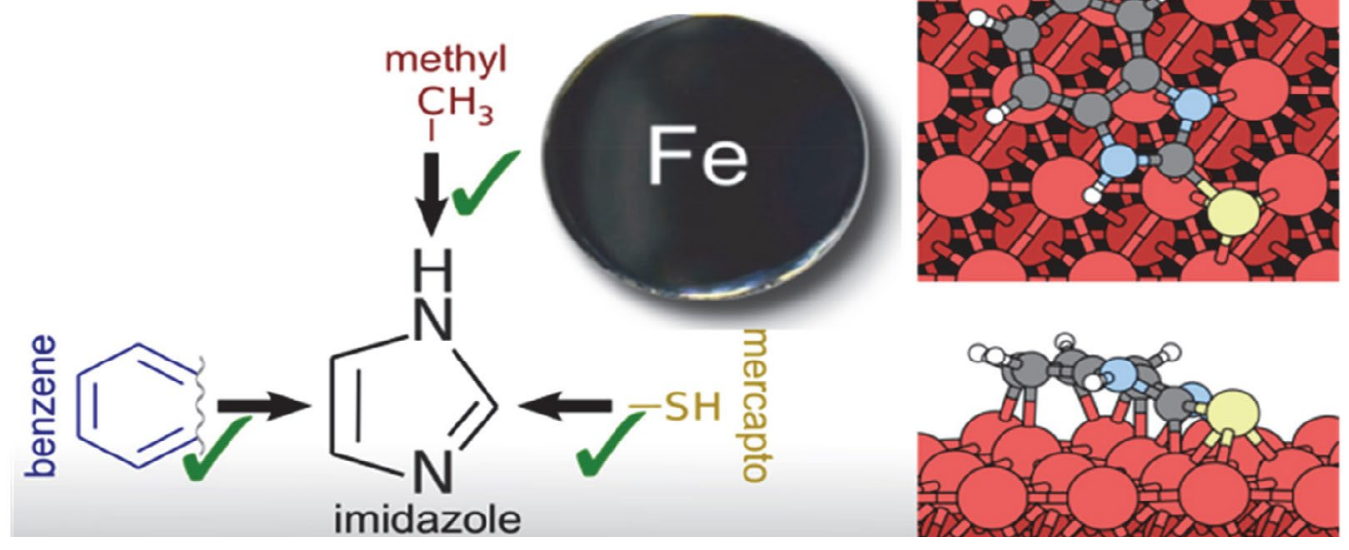

Figure 8. The inhibition efficiency as a function of imidazole derivative and substrate for (a) copper and (b) iron. (b) Optimized molecular adsorption modes of SH-BimMe on iron surface. (a) Reprinted from the publication by I. Milošev, N. Kovačević, A. Kokalj, Corros. Sci., 2015, 98, 107-118 with permission from Elsevier. ${ }^{48}$

pared to that of corrosive species such as chloride is relevant. ${ }^{52}$ This finding confirms that the inhibition effect of given inhibitor is strongly dependent on the substrate and that efficiency of the inhibitor cannot be predicted per se without considering the substrate as well. ${ }^{52}$

Other organic compounds were also considered as corrosion inhibitors, specifically in context of using environmentally friendly compounds. We considered amino acids and naturally driven compounds, such as phytic acid which is in chemical structure inositol hexaphosphate (IP6). ${ }^{53}$ When copper surface is optimally pre-treated, i.e. roughened in sulphuric acid, and then immersed in 0.01 $\mathrm{mM}$ phytic acid the inhibition efficiency of $77 \%$ was achieved in $\mathrm{NaCl}$ solution. Among 11 amino acids tested, cysteine achieved the highest inhibitor efficiency reaching $52 \%$ at a concentration of $10 \mathrm{mM}$. $^{54}$ Thiol (mercapto) group was shown to be responsible for superior inhibition efficiency compared to other amino acids among which some acted even as corrosion activators.

\section{1. Synergistic Action of Inhibitors}

One of the recent trends in corrosion protection is the synergistic use of inhibitors. The combination of differ- ent inhibitors can either increase the effect of each inhibitor individually, or bring additional functional property, for examples hydrophobicity. $55,56,57,58,59,60,61$ Illustrative example is the combination of classical inhibitors for copper and copper-based alloys-2-mercapto benzimidazole $\left(\mathrm{SH}-\mathrm{BimH}^{2}\right)$ and benzotriazole (BTAH)-and carboxylic acids. ${ }^{57,58,59,60,61}$ Immersion of metal in a solution containing carboxylic acid, especially those with long alkyl chain, results in the formation of carboxylate layer at the surface which contributes to hydrophobicity of the surface.

$$
\begin{aligned}
& \mathrm{Cu}^{+}+\mathrm{CH}_{3}\left(\mathrm{CH}_{2}\right)_{\mathrm{m}} \mathrm{COOH} \rightarrow \\
& \rightarrow \mathrm{Cu}\left[\mathrm{CH}_{3}\left(\mathrm{CH}_{2}\right)_{\mathrm{m}} \mathrm{COO}\right]+\mathrm{H}^{+}
\end{aligned}
$$

The combination of octadecanoic (stearic) acid (SA) and $\mathrm{SH}-\mathrm{BimH}$ will be described as an example. Inhibitor layers were prepared by self-assembly in ethanol solution of inhibitors, either as individual (SA and SH-BimH), binary $(\mathrm{SH}-\mathrm{BimH} / \mathrm{SA})$ and mixed $(\mathrm{SH}-\mathrm{BimH}+\mathrm{SA})$. Corrosion properties were evaluated in simulated urban rain (0.2 g/L Na $2 \mathrm{SO}_{4}, 0.2 \mathrm{~g} / \mathrm{L} \mathrm{NaHCO}_{3}$ and $0.2 \mathrm{~g} / \mathrm{L} \mathrm{NaNO}_{3}$,

2 2-mercaptobenzimidazole was denoted 2-MBI in original publication. ${ }^{57,58,59,60,61}$ 
$\mathrm{pH}=5$ ). This medium was chosen due to application of copper-based alloys, such as bronze and brass, for outdoor infrastructures and monuments. Under simulated urban rain conditions, the combination of $\mathrm{SH}-\mathrm{BimH}$ and $\mathrm{SA}$ achieved much better inhibition efficiency compared to individual inhibitors (Fig. 9). ${ }^{57}$ The morphology of the individual layers is quite different. After immersion in SA, the surface was covered by a flower-like features leaving an open substrate surface. In contrast, immersion in SH$\mathrm{BimH}$ resulted in the formation of a compact nano-grain layer covered with longitudinal features. When SA and SH-BimH were combined, an uneven surfaces with large cuffs, which is interpreted as accounting for the hydrophobicity of the layer with contact angles exceeding $110^{\circ}$.

Electrochemical potentiodynamic measurements in simulated urban rain revealed differences in the mechanism of corrosion inhibition (Fig. 9b). ${ }^{57}$ Both inhibitors act as mixed inhibitors, i.e. affect both cathodic and anodic current density, but SH-BimH shifts the corrosion potential more in the cathodic direction. Both combinations of SH-BimH and SA, i.e. formed one layer above another, or mixed within one layer, exhibited three orders magnitude smaller current density compared to that of individual inhibitors. Therefore, the layers formed by the combination of stearic acid and organic inhibitors achieve improved corrosion protection ability and offer hydrophobicity as an additional functional property. Further reading offer details on the use of carboxylic acid of different chain length as inhibitors of copper corrosion, and $\mathrm{SH}-\mathrm{BimH}$ and BTAH combined with stearic acid as corrosion inhibitors for $\mathrm{Cu}-10 \mathrm{Zn}, \mathrm{Cu}-40 \mathrm{Zn}$ and $\mathrm{Zn} .{ }^{59,60}$ Synergistic increase of corrosion resistance when combining $\mathrm{SH}-\mathrm{BimH}$ or BTAH with stearic acid was attributed to the carboxylate formation process of SA, reaction (13), which acts as a barrier, whereas BTAH and SH-BimH adsorb on the $\mathrm{Cu}$ surface according to their well-known corrosion inhibition mechanism. ${ }^{37,38,39,47,49,50}$ These two processes occur simultaneously.

\section{Conversion Coatings (Based on Rare Earth Salts)}

Conversion coatings can be defined as coatings formed by conversion from soluble salt to a slightly soluble or insoluble oxide and/or hydroxide which precipitates either throughout the metal surface, or at intermetallic particles which are electrochemically more noble in respect to surrounding matrix and where oxygen reduction takes place. ${ }^{62}$ Today two main types of conversion coatings are being explored on aluminium alloys: rare earth coatings ${ }^{63}$ or zirconium and/or titanium coatings. ${ }^{21}$ Inhibitory action of these conversion coatings is based on the retardation of cathode reaction (i.e. oxygen evolution) on corroding surfaces.

Rare earth compounds are environmentally friendly, exhibit low toxicity and are available in natural sources at a reasonable price. Hinton et al. were the first to observe that rare earth salts, especially cerium, inhibit redox reaction on aluminium alloys. ${ }^{62}$ Precipitation of rare earth hydroxide deposits is $\mathrm{pH}$-driven process which starts at cathodic sites on the aluminium alloy surface that are electrochemically less negative (more noble) relative to aluminium matrix. ${ }^{62,63}$ Depending on the cation, $\mathrm{Ce}(\mathrm{OH})_{3}, \mathrm{La}(\mathrm{OH})_{3}$, $\mathrm{Nd}(\mathrm{OH})_{3}$, etc. are formed once the critical $\mathrm{pH}$ for their deposition is reached. For Ce, critical value is above $\mathrm{pH}$ 9.5. ${ }^{64}$ Among rare earth compounds mainly cerium and lanthanum have been investigated and show the highest potential for further applications, although compounds of
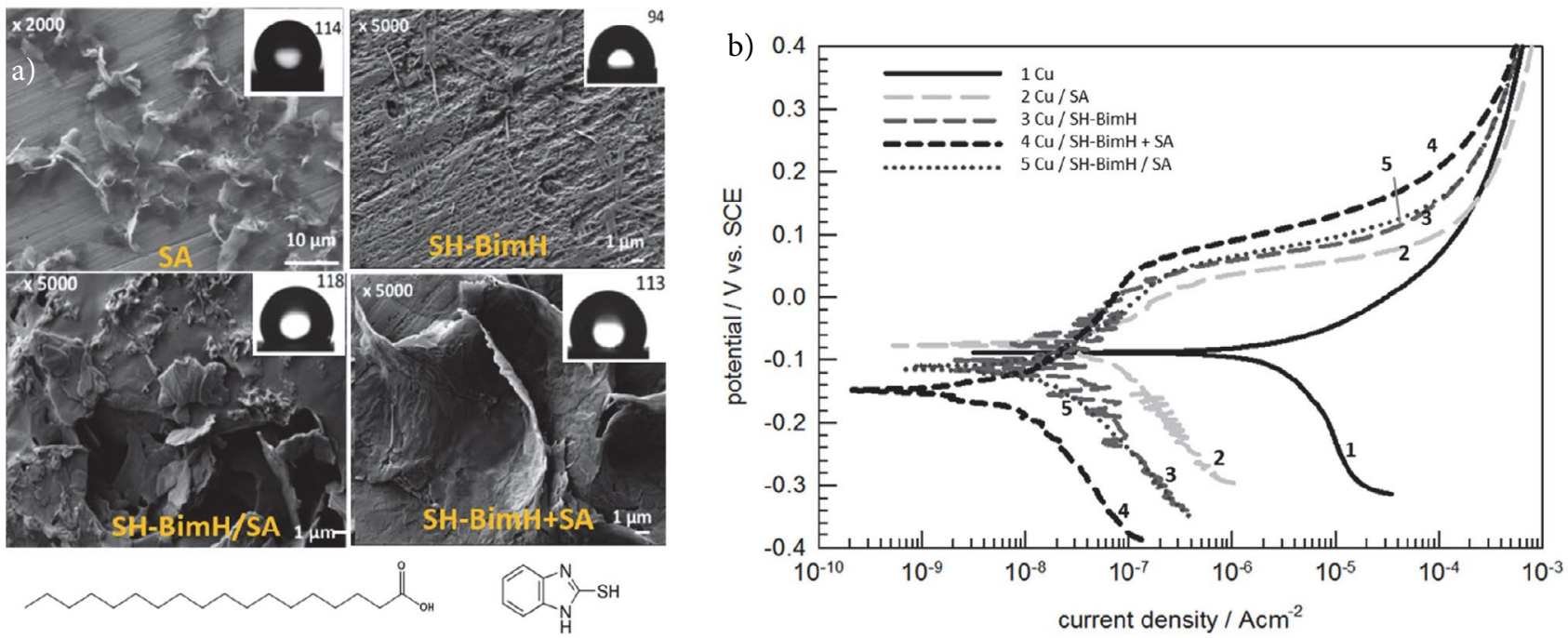

Figure 9. (a) SEM images of copper surface in ethanol solution of different organic compounds: immersed for 20 minutes in $0.05 \mathrm{M}$ octadecanoic (stearic) acid (SA), immersed for $1 \mathrm{~h}$ in $0.01 \mathrm{M}$ 2-mercaptobenzimidazole (SH-BimH), $1 \mathrm{~h}$ in $0.01 \mathrm{M} 2$-MBI followed by 20 minutes in $0.05 \mathrm{M}$ SA (SH-BimH/SA), and $1 \mathrm{~h}$ in mixture of $0.01 \mathrm{M} \mathrm{SH-BimH}$ and $0.05 \mathrm{M} \mathrm{SA}$. (b) Polarization curves recorded for bare copper and modified by inhibitors after $1 \mathrm{~h}$ immersion in simulated urban rain. $\mathrm{d} E / \mathrm{d} t=1 \mathrm{mV} / \mathrm{s}$. Skeletal formulae of SA and 2-MBI are presented. (Reprinted from the publication by G. Žerjav, I. Milošev, Corros. Sci., 2015, 98, 180-191 with permission from Elsevier. ${ }^{57}$ ) 
other rare earth elements like neodymium and praseodymium have also been addressed. ${ }^{63}$ Different types of salts have been used, i.e. chloride, nitrites, acetate, sulphate and dibuthyl-phosphate. Conversion of rare earth salts to hydroxides can be accelerated by the addition of hydrogen peroxide whose role is three-fold - a complexing agent, an oxidant and a crystallisation inhibitor. ${ }^{65}$

Cathodic curve in potentiodynamic polarization curve is related to reduction of dissolved oxygen which can proceed through $4 \mathrm{e}^{-}$reaction, reaction (1), or $2 \mathrm{e}^{-}$reaction, reaction (14). ${ }^{65}$

$$
\mathrm{O}_{2}(\mathrm{aq})+2 \mathrm{H}_{2} \mathrm{O}+2 \mathrm{e}^{-} \rightarrow \mathrm{H}_{2} \mathrm{O}_{2}(\mathrm{aq})+2 \mathrm{OH}^{-}(\mathrm{aq})
$$

In reaction (1) $\mathrm{O}_{2}$ is completely reduced to hydroxyl $\left(\mathrm{OH}^{-}\right)$, while in reaction (14) $\mathrm{O}_{2}$ is reduced to $\mathrm{OH}^{-}$and $\mathrm{H}_{2} \mathrm{O}_{2}$. Alkalization caused by reactions (1) and (14) reaches $\mathrm{pH}$ above 9.5 required for precipitation of $\mathrm{Ce}(\mathrm{OH})_{3}{ }^{64}$ Polarization curve recorded for AA7075-T6 in NaCl solution are presented in Fig. 10. $E_{\text {corr }}$ is $-0.70 \mathrm{~V}$, and $j_{\text {corr }} 1.9$ $\mu \mathrm{A} \mathrm{cm}^{-2}$. AA7075-T6 is highly susceptible to corrosion in chloride environment. The rapid increase in anodic current density with increasing potential is associated with the pitting corrosion related to dissolution of IMPs. ${ }^{21,27}$ The addition of $\mathrm{Ce}$ (III) salts to $\mathrm{NaCl}$ solution improved corrosion properties of AA7075-T6, resulting in reduced $j_{\text {corr }}$ a shift in $E_{\text {corr }}$ and the appearance of a passive region (Fig. 10a) ${ }^{66}$ In the presence of $\mathrm{CeCl}_{3}$ and $\mathrm{Ce}(\mathrm{Ac})_{3} E_{\text {corr }}$ was shifted more negative by more than $200 \mathrm{mV}$. The cathodic current density was significantly reduced. This behaviour is typical for efficient cathodic inhibitors, as described by Hinton et al. ${ }^{62}$ The absence of pitting was ascribed to displacement of $E_{\text {corr }}$ away from $E_{\text {pit }}$ in the negative direction. The span of $\Delta E=\left|E_{\text {corr }}-E_{\text {pit }}\right|$ is taken as the measure of initiation of pit nucleation. ${ }^{62}$ The effect of $\mathrm{Ce}\left(\mathrm{NO}_{3}\right)_{3}$ was, however, different, i.e., it changed the value of $E_{\text {corr }}$ to more positive and slowed down the dissolution, due to the stimulation of oxide formation. ${ }^{66}$

The range of cerium distribution over the surface of AA7075-T6 immersed for $24 \mathrm{~h}$ in $\mathrm{NaCl}$ with added $3 \mathrm{mM}$ $\mathrm{CeCl}_{3}$ or $\mathrm{Ce}(\mathrm{Ac})_{3}$ was investigated SEM/EDS mapping (Fig. 10b) ${ }^{67}$ After immersion in $\mathrm{NaCl}$, corrosion is located on IMPs as these electrochemically differ from surrounding alloy matrix and are sites where localized corrosion begins. ${ }^{67}$ The deposition of cerium oxide proceeds at IMPs containing copper as these sites present the sites of oxygen reduction where alkalization required for precipitation of cerium oxide is the highest. ${ }^{68}$ The formation of Ce(III) oxide can be presented as:

$$
\mathrm{Ce}^{3+}+3 \mathrm{OH}^{-} \rightarrow \mathrm{Ce}(\mathrm{OH})_{3}(\mathrm{~s})
$$

The precipitated area is rich in Ce and $\mathrm{O}$ conforming the formation of cerium oxide (Fig. 10b). The XPS analysis, which can differentiate between different oxidation states of an element, confirmed that the oxides formed usually contain a mixture of $\mathrm{Ce}(\mathrm{III})$ and $\mathrm{Ce}(\mathrm{IV}) .{ }^{68}$ In the sample immersed in $\mathrm{Ce}(\mathrm{Ac})_{3}$, Ce is identified in much higher concentrations than in the sample immersed in $\mathrm{CeCl}_{3}$ (Fig. 10b). Cerium is detected in bright agglomerates at the matrix surface, as well as in a large gray IMPs.

The presented results show that the efficiency of rare earth conversion coating is dependent on type of anion. Following example will prove that it is dependent also on the type of cation. In the presence of $\mathrm{CeCl}_{3}$ the cathodic current density was one order of magnitude smaller (Fig. 11a) with a strong cathodic shift of $E_{\text {corr }}{ }^{69}$ When $\mathrm{LaCl}_{3}$ was added, however, cathodic current density was smaller to lesser extent than for $\mathrm{CeCl}_{3}$ and $E_{\text {corr }}$ shifted more negative by only $10 \mathrm{mV}$. Thus, the effect of adding $\mathrm{LaCl}_{3}$ was less than that of adding $\mathrm{CeCl}_{3}$.

Similar as for inhibitors, we explored the possibility to improve the efficiency of conversion coatings by acting synergistically, i.e. combining different rare earth salts. ${ }^{69,70,71}$ In the presence of mixtures of $\mathrm{CeCl}_{3}$ and $\mathrm{LaCl}_{3}$ in $\mathrm{NaCl}$ solution the cathodic curves were shifted in a more negative direction by approximately $200 \mathrm{mV}$, resulting in an $E_{\text {corr }}$ of $-0.84 \mathrm{~V}$ (Fig. 11a). ${ }^{69}$ The values of $j_{\text {corr }}$ were smaller than in the presence of $\mathrm{CeCl}_{3}$ or $\mathrm{LaCl}_{3}$ alone. Thus, when added together to the solution, the two inhibitors act synergistically, since better results were achieved than when used individually. At a constant inhibitor concentration of $0.01 \mathrm{M}$ the effect of mixing different inhibitors is slightly beneficial for $\mathrm{CeCl}_{3}$ but especially so for $\mathrm{LaCl}_{3}$, which show improved inhibition effectiveness when mixed with $\mathrm{CeCl}_{3}$. As lanthanum compounds are in general less effective than cerium compounds, mixing with cerium is a method for improving its protectiveness in near neutral chloride medium.

Compositional SEM images ${ }^{3}$ revealed that rare earth deposits are formed primarily over IMPs (Fig. 11b). ${ }^{69}$ Deposits formed in $\mathrm{CeCl}_{3}$ containing solution are round are thick containing Ce oxide, reaction (15). Deposits formed in $\mathrm{LaCl}_{3}$ solution are smaller, thinner and contain La oxide which is formed according to reaction:

$$
\mathrm{La}^{3+}+3 \mathrm{OH}^{-} \rightarrow \mathrm{La}(\mathrm{OH})_{3}(\mathrm{~s})
$$

The morphology of deposits formed in the mixture of $\mathrm{CeCl}_{3}$ and $\mathrm{LaCl}_{3}$ salts is the combination of individual $\mathrm{Ce}$ and La contributions: deposits were brighter than when using $\mathrm{LaCl}_{3}$ only, and less bright when using $\mathrm{CeCl}_{3}$ only (Fig. 11b). EDS spectra confirmed the formation of a mixed Ce- and La oxide and/or hydroxide. ${ }^{69,70}$

\section{1. Conversion Coatings with Active Function}

Important property of chromate coatings is the ability to repassivate when damaged. ${ }^{24,25,26,27}$ In search for chro-

3 In compositional SEM mode the heavier elements appear brighter than lighter elements. 
a)

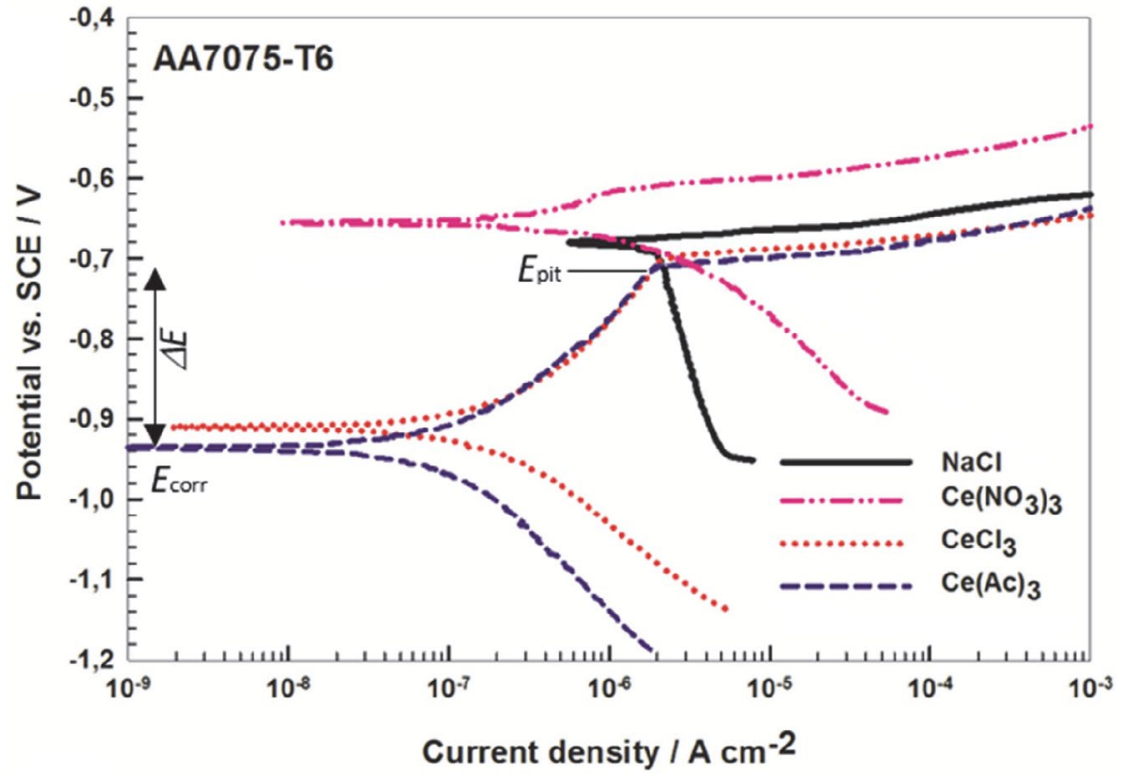

b)
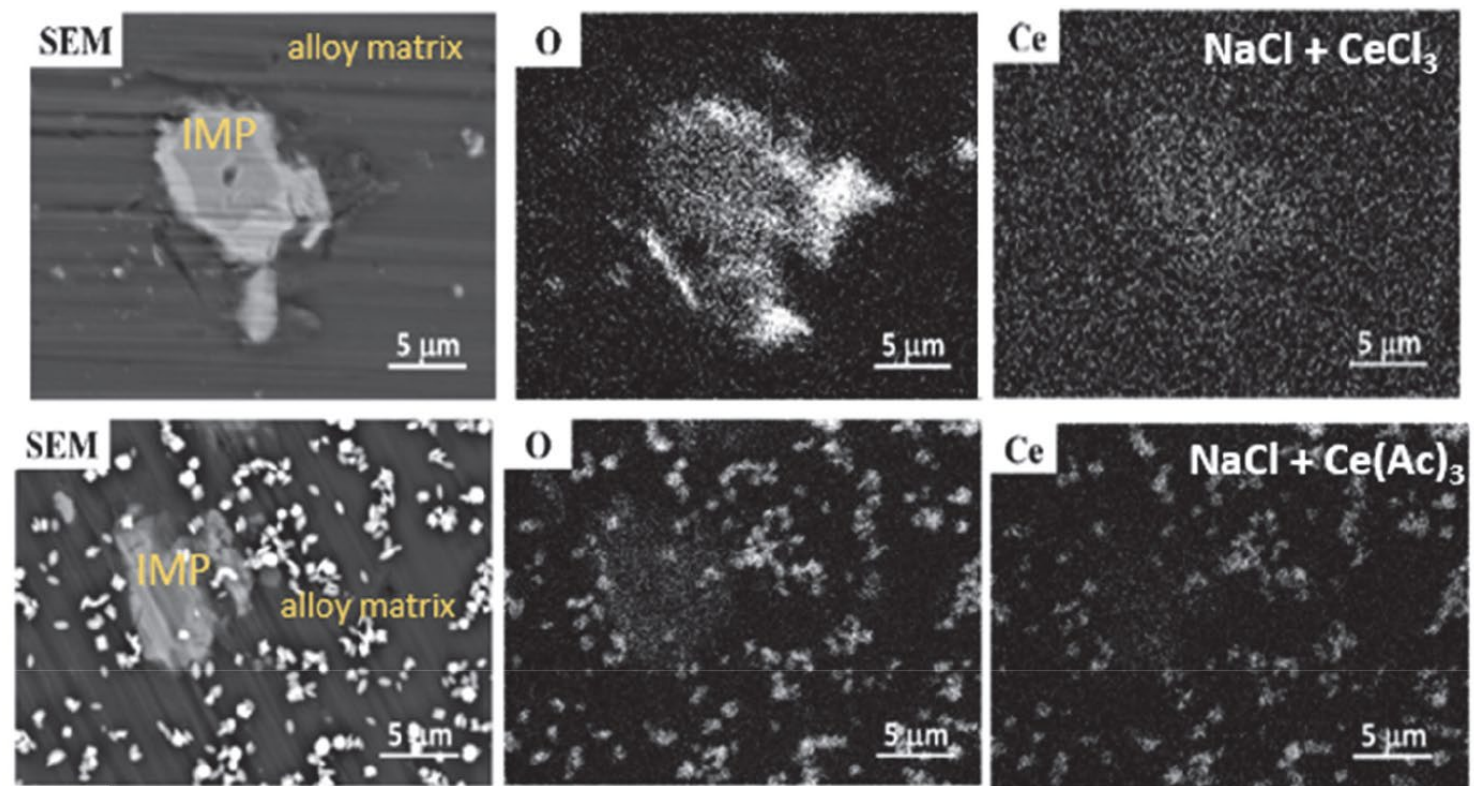

c)
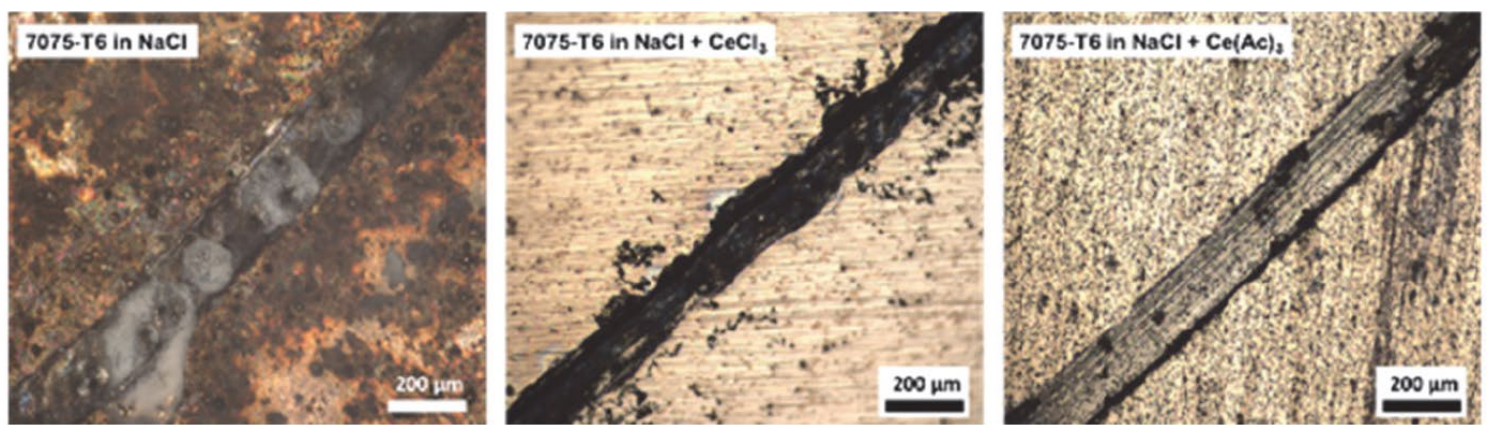

Figure 10. (a) Polarization curves recorded for aluminium alloy AA7075-T6 in $0.1 \mathrm{M} \mathrm{NaCl}$ solution with and without added $3 \mathrm{mM}$ cerium(III) nitrate, chloride and acetate salts. Corrosion potential $\left(E_{\text {corr }}\right)$, pitting potential $\left(E_{\mathrm{pit}}\right)$ and the span of passivity region $(\Delta E)$ are denoted. $\mathrm{d} E / \mathrm{d} t=1 \mathrm{mV} / \mathrm{s}$. (Reprinted from the publication by P. Rodič, I. Milošev, J. Electrochem. Soc., 2016, 163, C85-C93 with permission from The Electrochemical Society. ${ }^{66}$ ) (b) SEM images of AA7075-T6 immersed for $24 \mathrm{~h}$ in $0.1 \mathrm{M} \mathrm{NaCl}+3 \mathrm{mM} \mathrm{CeCl}_{3}$ and $3 \mathrm{mM} \mathrm{Ce}(\mathrm{Ac})_{3}$ for $24 \mathrm{~h}$ and EDS mapping for O and Ce elements.(c) Confocal microscope images of artificially made scratch on AA7075-T6 after $72 \mathrm{~h}$ immersion in $0.1 \mathrm{M} \mathrm{NaCl}$ and $0.1 \mathrm{M} \mathrm{NaCl}$ with added $3 \mathrm{mM} \mathrm{CeCl}_{3}$ and $3 \mathrm{mM} \mathrm{Ce}(\mathrm{Ac})_{3}$. (Reprinted from the publication by I. Milošev, P. Rodič, Corrosion, 2016, 72, 1021-1034 with permission from NACE. ${ }^{67}$ 

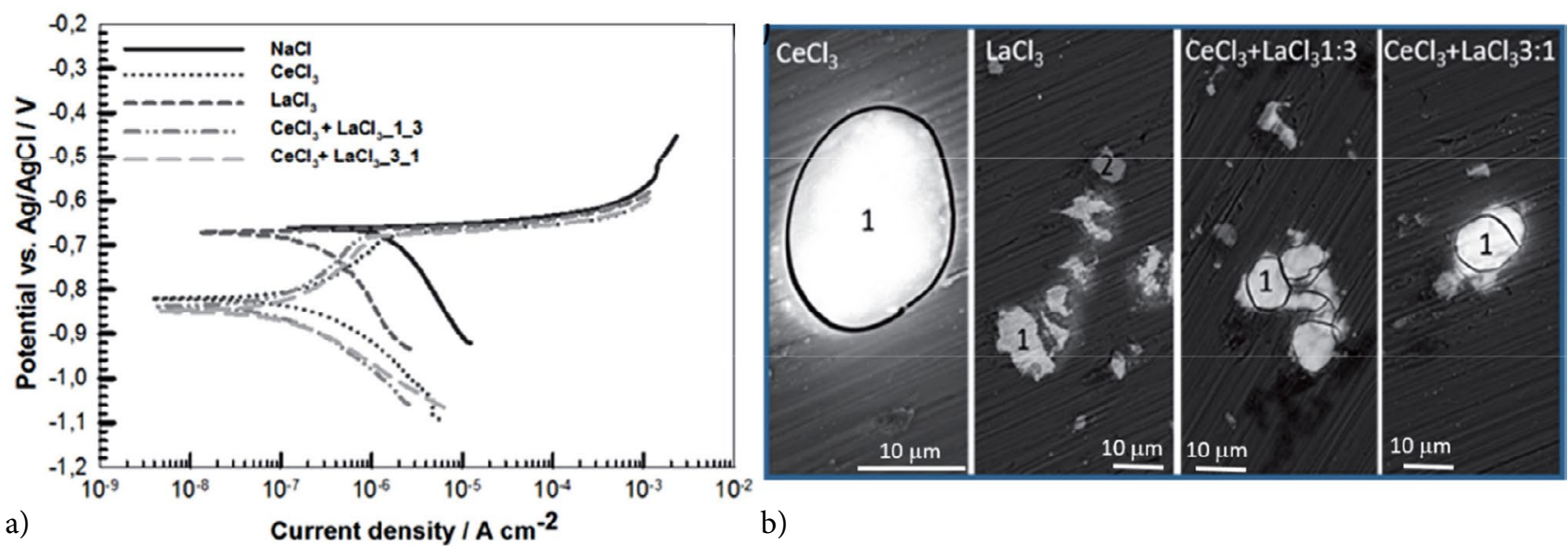

b)

Figure 11. a) Polarization curves recorded for aluminium alloy AA7075-T6 in $0.1 \mathrm{M} \mathrm{NaCl}$ solution with and without added $0.01 \mathrm{M}$ cerium(III) chloride, lanthanum(III) chloride and their mixtures in ratio 1:3 and 3.1. $\mathrm{d} E / \mathrm{d} t=1 \mathrm{mV} / \mathrm{s}$. (b) SEM images recorded in compositional mode of AA7075-T6 immersed for $12 \mathrm{~h}$ in $0.1 \mathrm{M} \mathrm{NaCl}$ with added $\mathrm{CeCl}_{3}, \mathrm{LaCl}_{3}$ and their mixtures. (Reprinted from the publication by B. Volarič, I. Milošev, Corr. Eng. Sci. Technol., 2017, 52, 201-211 with permission from Taylor \& Francis. ${ }^{69}$ )

mate replacement alternatives it is therefore necessary to inspect also this ability. Self-healing, active protection and self-repassivation are terms used to denote the ability of the coating to recover after damage. ${ }^{72}$ Cerium based coating exhibit this ability due to the existence of two oxidation states, $\mathrm{Ce}(\mathrm{III})$ and $\mathrm{Ce}(\mathrm{IV})$, which are in dynamic equilibrium. ${ }^{62}$ In order to investigate the self-healing, the surface has to be artificially damaged, and the repassivation over damaged is then followed. Optical microscope images of the scratched surface after $48 \mathrm{~h}$ immersion in $0.1 \mathrm{M} \mathrm{NaCl}$ with and without addition of $3 \mathrm{mM} \mathrm{CeCl}_{3}$ and $3 \mathrm{mM}$ $\mathrm{Ce}(\mathrm{Ac})_{3}$ are presented in Fig. $10 \mathrm{c} .{ }^{67}$ Scratched surface could not repassivate in $\mathrm{NaCl}$ solution and the scratch was filled with voluminous whitish corrosion product. When $\mathrm{CeCl}_{3}$ was added to $\mathrm{NaCl}$ solution, the surface within the scratch remained black but without corrosion product. Surrounding surface was protected, unlike in $\mathrm{NaCl}$, preserving a metallic appearance. When $\mathrm{Ce}(\mathrm{Ac})_{3}$ was present in the solution, the scratch was covered with the same layer as the surrounding surface, proving the repassivation within the defect. ${ }^{67}$ The ability to repassivate and self-heal the surface defects during immersion in chloride solution is based on the dynamic equilibrium between $\mathrm{Ce}(\mathrm{III})$ and $\mathrm{Ce}(\mathrm{IV})$ species which eventually results in the formation of almost insoluble hydroxide and oxide within defects. ${ }^{62,63,65}$

The mechanism of oxidation of Ce(III) to Ce(IV) can proceed via two alternative paths. $\mathrm{O}_{2}$ can act as oxidant and $\mathrm{Ce}(\mathrm{III})$ as a reductant: ${ }^{63,65}$

$$
\begin{aligned}
& 4 \mathrm{Ce}^{3+}(\mathrm{aq})+\mathrm{O}_{2}(\mathrm{aq})+4 \mathrm{OH}^{-}(\mathrm{aq})+2 \mathrm{H}_{2} \mathrm{O} \rightarrow \\
& \rightarrow 4 \mathrm{Ce}(\mathrm{OH})_{2}^{2+}(\mathrm{aq})
\end{aligned}
$$

or may be reduced at cathodic sites, generating $\mathrm{H}_{2} \mathrm{O}_{2}$ which can then oxidize $\mathrm{Ce}(\mathrm{III})$ to $\mathrm{Ce}(\mathrm{IV})$ :

$$
\begin{aligned}
& 2 \mathrm{Ce}^{3+}(\mathrm{aq})+\mathrm{H}_{2} \mathrm{O}_{2}(\mathrm{aq})+2 \mathrm{OH}^{-}(\mathrm{aq}) \rightarrow \\
& 2 \mathrm{Ce}(\mathrm{OH})_{2}^{2+}(\mathrm{aq})
\end{aligned}
$$

The soluble Ce(IV) species then precipitate as insoluble $\mathrm{CeO}_{2}$ due to the local rise in $\mathrm{pH}$ caused by the production of $\mathrm{OH}^{-}$ions: ${ }^{63,65}$

$$
\begin{aligned}
& \mathrm{Ce}(\mathrm{OH})_{2}^{2+}(\mathrm{aq})+2 \mathrm{OH}^{-}(\mathrm{aq}) \rightarrow \mathrm{Ce}(\mathrm{OH})_{4}(\mathrm{~s}) \rightarrow \\
& \rightarrow \mathrm{CeO}_{2}(\mathrm{~s})+2 \mathrm{H}_{2} \mathrm{O}
\end{aligned}
$$

It was shown that the solubility of precipitated layer can be further reduced by the addition of sulphate ions resulting in the formation of $\mathrm{Ce}(\mathrm{OH})_{\mathrm{a}}\left(\mathrm{SO}_{4}\right)_{\mathrm{b}}$ product. $^{73}$

\section{Sol-Gel Coatings}

\section{1. Barrier Sol-Gel Coatings}

In the last two decades sol-gel coatings have been extensively studied for corrosion protection applications. ${ }^{74}$ According to the definition, sol-gel is every process which starts from the precursor's solution and goes through the stage of sol and $\mathrm{gel} .{ }^{75} \mathrm{Sol}$ is a stable suspension of colloidal particles within a liquid, and gel is a rigid and interconnected network. Precursors can be inorganic and organic, nowadays usually hybrid sol-gels are explored which consist of both inorganic and organic precursors. Inorganic precursors are metal alkoxides $\mathrm{M}(\mathrm{OR})_{4}$ and organic precursors are organic alkoxides $(\mathrm{R}-\mathrm{O})_{4-\mathrm{n}} \mathrm{MR}_{\mathrm{n}}$, where $\mathrm{M}$ represents a network-forming element $(\mathrm{Si}, \mathrm{Ti}, \mathrm{Zr}, \mathrm{Al}), \mathrm{R}$ is an alkyl group $\left(\mathrm{C}_{\mathrm{x}} \mathrm{H}_{2 \mathrm{x}+1}\right)$, and $\mathrm{R}_{\mathrm{n}}{ }^{\prime}$ is carbon chain containing functional group, e.g. epoxy, amino, etc. Precursors can be transformed to a gel by chemical transformation, i.e. hydrolysis of metal alkoxide, where $(-\mathrm{OR})$ groups are replaced by $(-\mathrm{OH})$ groups, in the presence of water and catalyst (acid or basic), and polycondensation of hydroxyl groups leading to a gel network. The conversion of the precursors into hybrid sol-gel coatings proceeds through the formation of $\mathrm{M}-\mathrm{O}-\mathrm{M}$ bonds. 


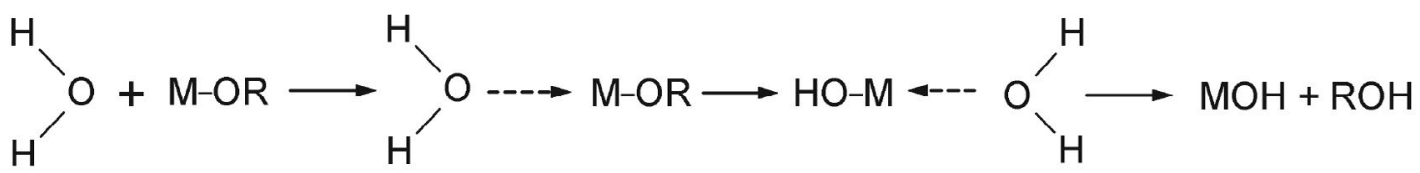

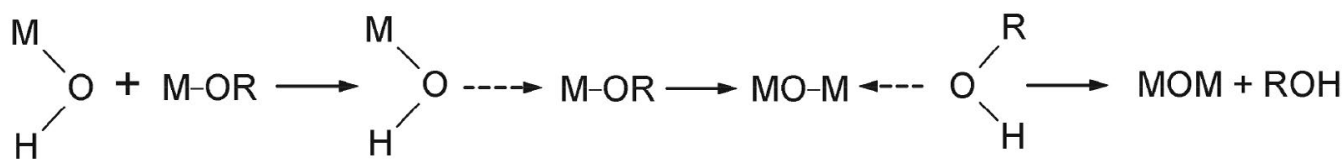

Sol-gel can be applied to metal surface using various techniques, such as dipping, spinning, spraying. Once deposited onto a metal surface, sol-gel coating is subjected to thermal treatment (or curing) for final condensation and densification. Due to complex chemical transformations it is necessary to use versatile methodology for sol and coating characterization. ${ }^{76}$ Chemical transformations within the sol were studied using in situ Fourier transform infrared spectroscopy (FTIR), ${ }^{1} \mathrm{H}$ and ${ }^{29} \mathrm{Si}$ liquid state NMR (nuclear magnetic resonance) spectroscopy, dynamic light scattering (DLS), UV-vis-NIR spectroscopy and thermogravimetric analysis (TGA). Chemical composition and morphology of the coatings were characterized using attenuated total reflectance FTIR (ATR FTIR), $\mathrm{X}$-ray diffraction (XRD), glow discharge optical emission spectroscopy (GDOES), X-ray photoelectron spectroscopy (XPS), time-of-flight secondary ion mass spectrometry (ToF-SIMS), transmission electron microscopy (TEM) a)

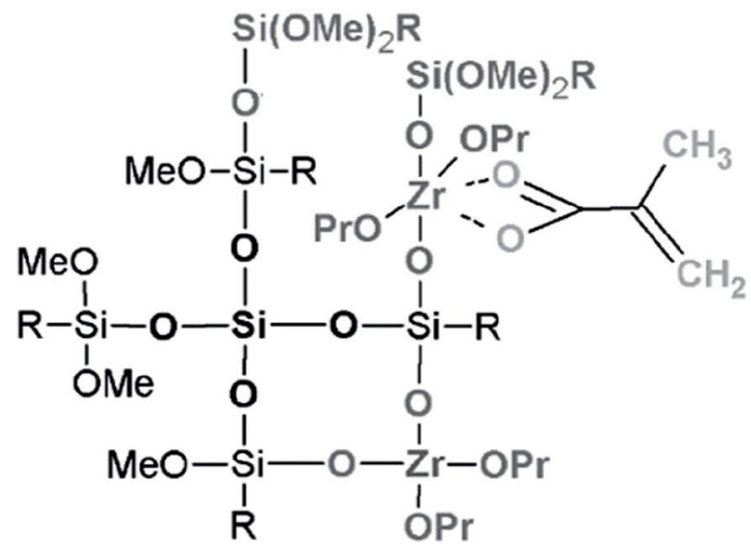

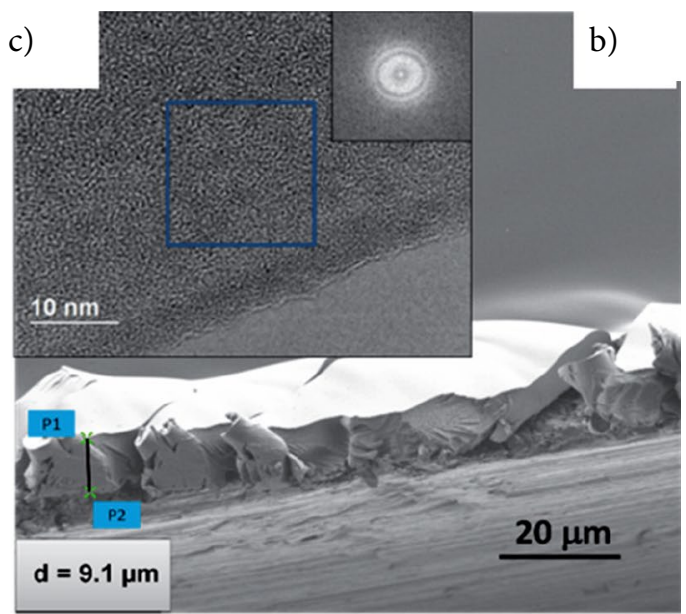

d)

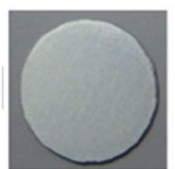

$\mathbf{O h}$

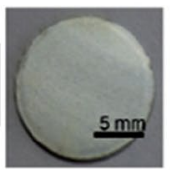

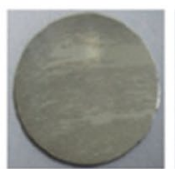

$12 \mathrm{~h}$

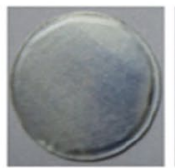

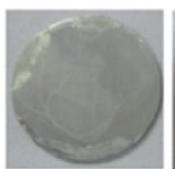

$24 \mathrm{~h}$

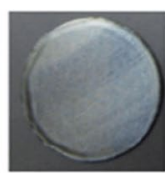

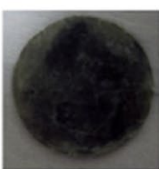

10 days

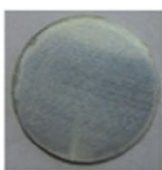

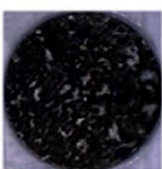

6 months

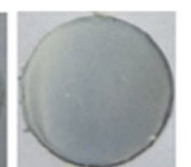

Figure 12. (a) Schematic presentation of the hybrid TMZ network formed by a sol-gel process using TEOS (tetraethyl orthosilicate), MAPTMS (3-methacryloxypropyl trimethoxysilane), ZTP (zirconium(IV) propoxide) and MMA (methacrylic acid). (Reprinted from the publication by P. Rodič, J. Iskra, I. Milošev, J. Non-Cryst. Solids, 2014, 396-397, 25-35 with permission from Elsevier. ${ }^{78}$ ) (b) SEM image of cross-section of TMZ coating showing homogeneous and dense structure. Coating thickness is cca. $9 \mu \mathrm{m}$ thick. (Reprinted from the publication by P. Rodič, A. Mertelj, M. Borovšak, A. Benčan, D. Mihailović, B. Malič, I. Milošev, Surf. Coat. Technol., 2016, 286, 388-396 with permission from Elsevier. ${ }^{79}$ ) (c) (TEM micrograph of amorphous TMZ coating with the corresponding fast Fourier transform (FFT) in the marked region. (Reprinted from the publication by P. Rodič, A. Mertelj, M. Borovšak, A. Benčan, D. Mihailović, B. Malič, I. Milošev, Surf. Coat. Technol., 2016, 286, 388-396 with permission from Elsevier. ${ }^{79}$ ) (d) Images of samples immersed in dilute Harrison's solution $\left(3.5 \mathrm{~g} / \mathrm{L}\left(\mathrm{NH}_{4}\right)_{2} \mathrm{SO}_{4}+0.5 \mathrm{~g} / \mathrm{L} \mathrm{NaCl}, \mathrm{pH}=5\right)$ for different periods of time: bare aluminium alloy A7075-T6 and coated with TMZ coating. (Reprinted from the publication by P. Rodič, I. Milošev, J. Electrochem. Soc., 2014, 161, C412-C420 with permission from The Electrochemical Society. ${ }^{80}$ ) 
and scanning electron microscopy with chemical analysis (SEM/EDS).

In our laboratory several hybrid sol-gel coatings were developed and will be briefly presented herein. TMZ coating is formed in a two-step process: (i) tetraethyl orthosilicate (TEOS) and 3-methacryloxypropyl trimethoxysilane (MAPTPS) were mixed and hydrolysed to obtained organosiloxane sol, and (ii) zirconium(IV) propoxide (ZTP) chelated with methacrylic acid (MAA) to obtain inorganic siloxane (skeletal formulae given below). After combining two sols, $\mathrm{Zr}$ initiates a condensation reaction that results in a network. ${ }^{77}$ After ageing of the sol the coating was deposited on AA7075-T6 aluminium alloy substrate and cured at $100{ }^{\circ} \mathrm{C}$. During that peried, the condensation reactions were completed with the formation of $\mathrm{Si}-\mathrm{O}-\mathrm{Si}$ and $\mathrm{Si}-\mathrm{O}-\mathrm{Zr}$ bonds (Fig. 12a). ${ }^{77,78}$ This transparent coating was up to $10 \mu \mathrm{m}$ thick, homogeneous and dense (Fig. 12b). ${ }^{79}$ No cracks or pores were formed. Based on XRD and TEM analyses we concluded that the coating is amorphous (Fig. 12c). ${ }^{79}$ Inclusion of zirconium in solgel network does not lead to the formation of nanoparticles but is rather randomly distributed within amorphous inorganic-organic polymerized silicon oxide matrix.

The corrosion resistance of synthesized hybrid TMZ coatings deposited onto AA7075-T6 substrate was investigated in dilute Harrison's solution $\left(3.5 \mathrm{~g} / \mathrm{L}\left(\mathrm{NH}_{4}\right)_{2} \mathrm{SO}_{4}, 0.5\right.$ $\mathrm{g} / \mathrm{L} \mathrm{NaCl}, \mathrm{pH} 5.2)$ which simulates aircraft conditions. ${ }^{80}$ The choice of solution stems from the use of this type of aluminium alloy in aerospace applications. Images of bare
AA7075-T6 sample and sample coated with TMZ coating are presented in Fig $12 \mathrm{~d}^{80}$ after immersion up to 6 months in dilute Harrison's solution. Corrosion of uncoated sample was visible after $12 \mathrm{~h}$, followed by progressive corrosion to the end of the test. In contrast, TMZ coating remained virtually unchanged by the end of the test.

Ageing and curing are beneficial due to improved condensation and polymerization of the network. ${ }^{81}$ This was proved by evaluation of content of different silanol species at different synthesis steps by ${ }^{29} \mathrm{Si} \mathrm{NMR}$ spectroscopy (Fig. 13). ${ }^{81}$ Skeletal formulae of TEOS, MAPTMS and ZTP are given in Fig. 13a. Hydrolysed sol containing only MAPTMS and TEOS contain mainly $\mathrm{T}_{1}$ species indicating the initial stage of condensation (Fig. 13b). The addition of ZTP chelated with MAA to hydrolysed siloxane sol was essential to induce the condensation reactions and formation of larger silicon domains resulting in a higher degree of polycondensation, i.e. higher content of $\mathrm{T}_{2}$ and $\mathrm{T}_{3}$ species. The latter increased further with ageing of the sol (Fig. 13c). The establishment of $\mathrm{Si}-\mathrm{O}-\mathrm{Si}$, and especially $\mathrm{Si}-\mathrm{O}-\mathrm{Zr}$, bonds is crucial to achieve excellent corrosion protection: a lower number of free silanol groups (fewer $T_{1}$ silicon species) and formation of more condensed $\mathrm{T}_{2}$ and $\mathrm{T}_{3}$ silicon species improved coating properties. ${ }^{81,83}$

TMZ coatings are acrylate-based (MAPTMS and MMA). Another type of coatings developed in our laboratory are GTS epoxy-based coating prepared from TEOS and 3-glycidoxypropyl-trimethoxysilane (GPTMS) as precursors (Fig. 14a). ${ }^{82}$ Silica $\mathrm{SiO}_{2}$ (Ludox) particles were

a)<smiles>C=C(C)C(=O)OCCC[Si](OC)(OC)OC</smiles>

(MAPTS)

Metacryloxypropyl-trimethoxysilane

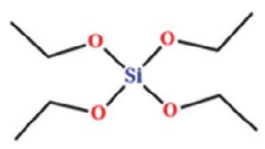

(TEOS)

Tetraethylorthosilicate

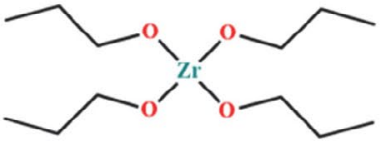

(ZTP)

Zirconium(IV) tetra-1-propoxide

b)<smiles>[R]CCC[Si](O)(O)O</smiles>

$T_{0}$

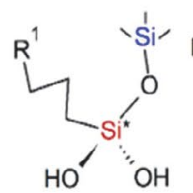

$\mathrm{T}_{1}$<smiles>[R]CCC[Si-](O)(O[SiH](C)C)O[SiH](C)C</smiles>

$\mathrm{T}_{2}$

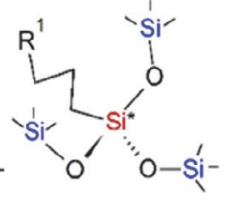

$\mathrm{T}_{3}$ c)

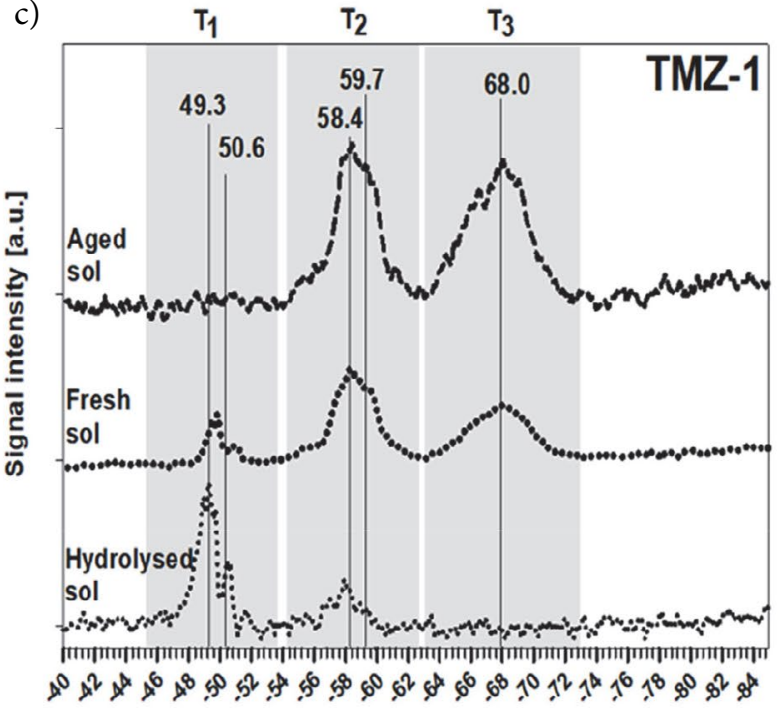

Chemical shift [ppm]

Figure 13. (a) Skeletal formulae of MAPTMS, TEOS and ZTP precursors for TZM coatings. (b) Different siloxane species with: three silanol groups $\left(\mathrm{T}_{0}\right)$, two silanol groups $\left(\mathrm{T}_{1}\right)$, one silanol group $\left(\mathrm{T}_{2}\right)$ and no silanol groups $\left(\mathrm{T}_{3}\right) .(\mathrm{c}){ }^{29} \mathrm{Si}$ NMR spectra for hydrolysed, fresh and aged TMZ-1 sol showing increasing content of $\mathrm{T}_{2}$ and $\mathrm{T}_{3}$ species with ageing of the sol. (Reprinted from the publication by P. Rodič, I. Milošev, M. Lekka, F. Andreatta, L. Fedrizzi, Prog. Org. Coat., 2018, 124, 286-295 with permission from Elsevier. ${ }^{81}$ ) 
a)

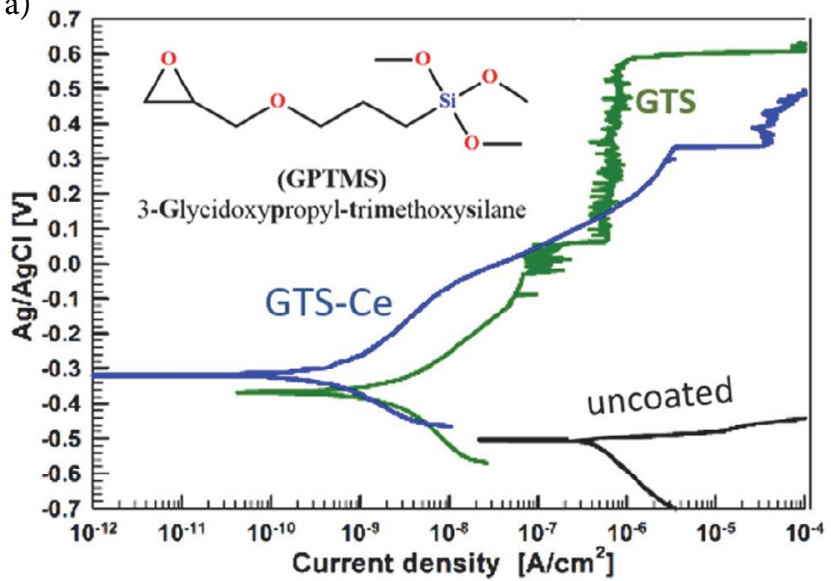

b)

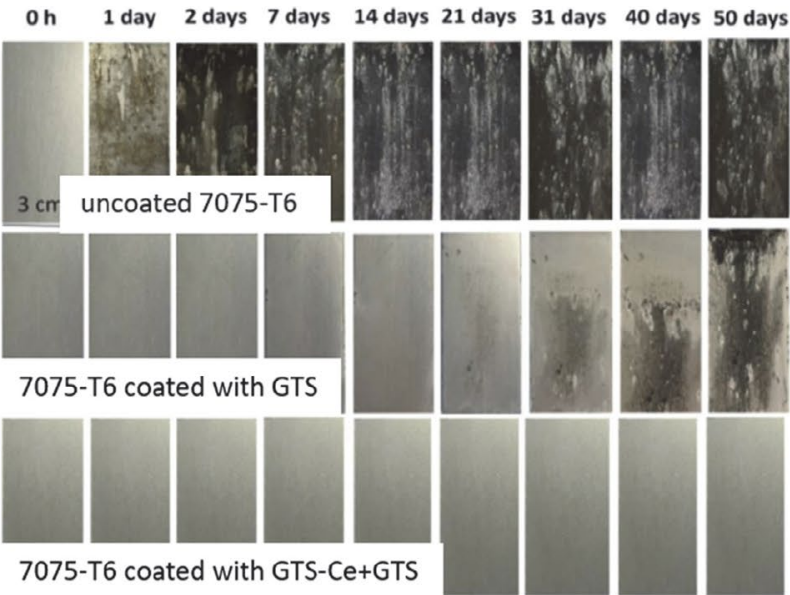

Figure 14. (a) Potentiodynamic polarization curves recorded in $0.1 \mathrm{M} \mathrm{NaCl}$, after $1 \mathrm{~h}$ stabilization for bare AA7075-T6 aluminium alloy and coated with GTS and GTS-Ce coatings. $\mathrm{d} E / \mathrm{d} t=1 \mathrm{mV} / \mathrm{s}$. (Reprinted from the publication by U. Tiringer, I. Milošev, A. Durán, Y. Castro, J. Sol-Gel Sci. Technol., 2018, 85, 546-557 with permission from Springer Nature. ${ }^{82}$ ) Skeletal formula of GPTMS is given in inset. (b) Images of uncoated aluminium alloy 7075-T6 and coated with GTS and GTS-Ce+GTS coatings during an immersion test in $0.1 \mathrm{M} \mathrm{NaCl}$. Images were takes at different times of immersion up to 50 days. (Reprinted from the publication by U. Tiringer, A. Durán, Y. Castro, I. Milošev, J. Electrochem. Soc., 2018, 165, C1-C13 with permission from The Electrochemical Society. ${ }^{87}$ )

added to achieve a barrier properties of coating. Organic polymerization with opening of the epoxy ring was initiated by the acidification and strong exothermic reaction. ${ }^{82}$ The polymerisation continued during the synthesis, in the liquid state, resulting in a more cross-linked and dense Si$\mathrm{O}-\mathrm{Si}$ network. The degree of inorganic and organic polycondensation were $93.3 \%$ and $80.3 \%$ indicating high degree of condensation, especially of inorganic network. Further improvements were achieved by addition of cerium ions, as will be shown below. ${ }^{83}$ Potentiodynamic polarization curves recorded in $0.1 \mathrm{M} \mathrm{NaCl}$ are presented for uncoated AA7075-T6 substrate and coated with GTS coating subjected to ramp heating up to $120{ }^{\circ} \mathrm{C}$ (Fig. 14a) ${ }^{82}$ Uncoated substrate exhibits poor corrosion resistance in chloride solution as evidenced by a strong increase in current density at potentials above $E_{\text {corr }}$. This increase is related to pitting and intergranular localized corrosion of the alloy. ${ }^{1,84}$

Polarization curves for substrate coated with GTS coating show reduced current density for several orders of magnitude and a shift of $E_{\text {corr }}$ to more positive values. The coating acts as an efficient barrier for preventing dissolution of substrate. This was proved also by immersion longterm testing in $\mathrm{NaCl}$ solution (Fig. $14 \mathrm{~b}$ ). Whilst uncoated AA7075-T6 substrate showed heavy corrosion already after 1 day, GTS-coated substrates did not show signs of corrosion up to 21 days.

\section{2. Sol-Gel Coatings with Active Function}

Hybrid sol-gel coatings used in corrosion protection act as barrier, i.e. prevent the penetration of electrolyte to underlying substrate due to their thickness up to ten micrometres, homogeneity and density. In real applications, barrier protection is often not sufficient to resist corrosion attack. Once damaged, coating will become permeable to aggressive medium eventually leading to corrosion of substrate. Once corrosion process begins, it cannot be stopped. One of the solutions is to incorporate inhibitors into solgel matrix which would then contribute the active recovery necessary to prolong the protection. ${ }^{85}$

Cerium salts are known inhibitors, as presented in previous section. Incorporation of cerium in the sol-gel coatings is associated with a more porous network enabling the release and migration of incorporated cerium ions within the coatings. ${ }^{82}$ It is noteworthy, however, that an optimal content of cerium should be incorporated since too large concentration may destruct the structural integrity of the coating. ${ }^{86,87}$ At the same time, it has to be assured that doping of the coating with cerium does not reduce the barrier properties of the coating, as cerium ions are bigger in size (1.978 $\AA$ ) compared to silicon atoms $(1.068 \AA)$. Larger Ce addition can cause lattice deformation and formation of nanopores and consequently change dramatically the characteristics of the coating. ${ }^{86}$

Self-healing of the coating can be followed electrochemically by measuring the open circuit potential $\left(E_{\mathrm{oc}}\right)^{86}$ or impedance at low frequency range. ${ }^{87}$ Upon immersion of TMZ coating, $E_{\mathrm{oc}}$ was cca. $-0.58 \mathrm{~V}$ and then shifted in more positive direction reaching $-0.42 \mathrm{~V}$ after approximately 9 days (Fig. 15a). ${ }^{86}$ However, at longer immersion times the values shifted to more negative values, due to the progressive degradation of TMZ coatings. On the other hand, for the TMZ-Ce coating, $E_{\mathrm{oc}}$ remained stable progressing in the positive direction. This behavior may be the consequence of cerium ions in the coating which increase barrier effect but may also contribute to the self-healing effect. 
a)

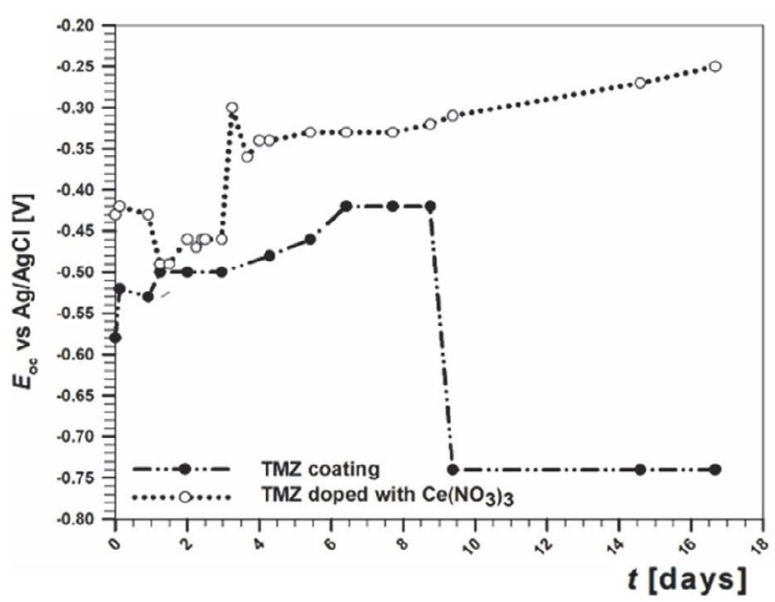

b)

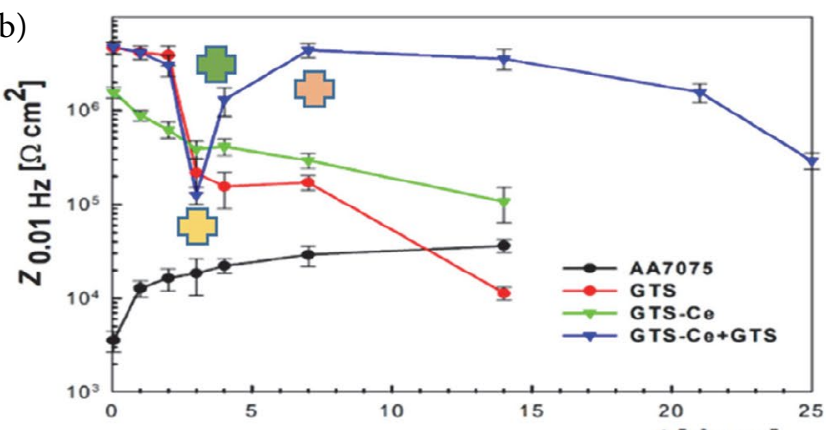

c)
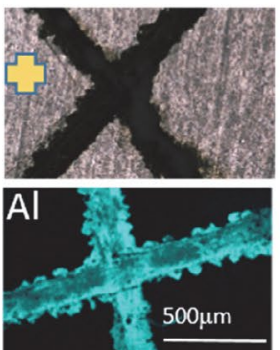

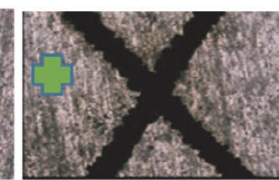

O

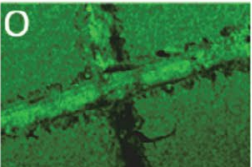

$\boldsymbol{t}$ [days]

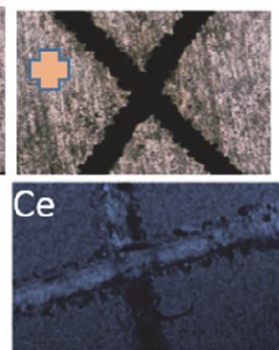

Figure 15. Electrochemical methods used to follow the self-healing of the sol-gel coating containing cerium inhibitor to assure active protection: (a) The dependence of open circuit potential (Eoc) on immersion time in $0.1 \mathrm{M} \mathrm{NaCl}$ for TMZ-3 and TMZ-3-Ce coatings. (Reprinted from the publication by P. Rodič, J. Katić, D. Korte, p.M. Desimone, M. Franko, S.M. Ceré, M. Metikoš-Huković, I. Milošev, Metals, 2018, 8, met8040248 with permission from MDPI. ${ }^{86}$ ) (b) Values of $\mathrm{Z}_{0.01 \mathrm{~Hz}}$ (impedance at $0.01 \mathrm{~Hz}$ ) determined from EIS spectra for scratched uncoated AA7075-T6 and coated with GTS, GTS-Ce and GTS-Ce+GTS coating as a function of immersion time in $0.1 \mathrm{M} \mathrm{NaCl}$. Crossed-shapes denote the time periods at which optical images in (c) were taken: yellow (3 days), green (4 days) and orange ( 7 days). (Reprinted from the publication by U. Tiringer, A. Durán, Y. Castro, I. Milošev, J. Electrochem. Soc., 2018, 165, C1-C13 with permission from The Electrochemical Society. ${ }^{87}$ ). (c) Optical images taken at different immersion periods and EDS mapping spectra for scratcedGTS-Ce+GTS coated AA7075-T6 after $72 \mathrm{~h}$ immersion. (Reprinted from the publication by U. Tiringer, A. Durán, Y. Castro, I. Milošev, J. Electrochem. Soc., 2018, 165, C1-C13 with permission from The Electrochemical Society. ${ }^{87}$ )

Cerium ions were added also to GTS coatings. ${ }^{82,83,87}$ GTS-Ce coatings exhibited enhanced corrosion properties, as shown by reduced current density in polarization curves (Fig. 14a) ${ }^{82}$ and excellent protection during longterm immersion up to 50 days in $\mathrm{NaCl}$ solution (Fig. 14b). ${ }^{87}$ It is noteworthy that the addition of cerium increases the lifespan of hybrid sol-gel coating and has a role in self-healing if it is locked within the first layer of the multilayer coating, denoted as GTS-Ce+GTS (Fig. 15b). ${ }^{87}$ Active role of cerium in the inhibition process was proved by long-term EIS measurements and immersion test on non-scribed and scribed coatings. Scribe was intentionally made by a diamond tip to simulate corrosion damage. As a decisive parameter, impedance at low frequency $\left(Z_{0.01 \mathrm{~Hz}}\right)$ was taken as it reflects the corrosion process at the substrate/coating interface (Fig. 15b). ${ }^{87}$ Upon immersion of scribed samples, impedance was decreasing with immersion time indicating that progressive penetration of electrolyte took place leading to corrosion of the substrate. Self-healing of the GTS-Ce+GTS coating starts after 4 days of immersion in $0.1 \mathrm{M} \mathrm{NaCl}$. After an initial decrease, the impedance at low frequency increased by more than one order of magnitude proving the self-healing process. Optical microscopy images of the scribed after 1, 3 and 4 days show that the damage re-passivate (Fig. 15c) ${ }^{87}$ EDS mapping of the scribed area proved the deposition of cerium within the scribe. Therefore, cerium ions are able to migrate within the coating and deposit in the form of insoluble hydroxide. As shown in previous section, cerium hydroxide reduces the kinetics of the cathodic reaction and overall corrosion process. XPS analysis showed that although gradually transformed into Ce(IV) hydroxide, reactions (17) (19), both oxidation states, $\mathrm{Ce}(\mathrm{III})$ and $\mathrm{Ce}(\mathrm{IV})$, were identified, even after 14 days of immersion, indicating that the self-healing process was still operative. The self-healing ability may be achieved by the migration of $\mathrm{Ce}(\mathrm{OH})_{2}{ }^{2+}$ to local damaged regions where these ions precipitate as $\mathrm{Ce}(\mathrm{OH})_{4}$ and $\mathrm{CeO}_{2}$, which are highly insoluble. The self-healing cycle can be repeated as long as $\mathrm{Ce}^{3+}$ are present in the coating. ${ }^{63}$ At a longer immersion time (21 days), the magnitude of impedance decreased, indicating diminished self-healing ability. However, the overall coating stability was still much higher than that of the coating without cerium (GTS), or single GTS-Ce coating (Fig. 14b). ${ }^{87}$

The addition of cerium to sol-gel has multifold effect. In addition to self-healing ability another important role is the effect on network formation. Cerium stimulates the polycondensation reaction at lower temperatures, in the inorganic and organic parts of hybrid sols. ${ }^{81,82,83,86}$ The role of cerium is ascribed to the fact that it can act as a 
Lewis acid and thus can facilitate the reaction of hydrolysis of the inorganic part and the polymerization of the organic phase of the network. ${ }^{83}$

Active protection or functionalization of the surface is beneficial not only against corrosion damage but also in other applications. Biomedical alloys like titanium alloys, cobalt chromium alloys and stainless steel are required to exhibit high corrosion resistance and biocompatibility, fatigue strength and high specific strength-to-weight ratios. $^{88}$ Advantageous abilities of biomedical alloys are the ability to osseointegrate and to resist bacteria attack. Whilst osseointegration assures stable long-term interface between bone and implant, resistance to adherence and colonization of bacteria on implant surface reduces the risk of infection.

Several types of sol-gel coatings were developed as functional coatings for biomedical alloys. ${ }^{89,90,91}$ Titanium dioxide $\left(\mathrm{TiO}_{2}\right)$ has received considerable attention in the field of materials science and has been extensively studied and prepared also by sol-gel methodologies. In majority of routes the obtained coatings were annealed up to $500{ }^{\circ} \mathrm{C}$ to obtain desired phase composition. Synthesis under acidic conditions using $\mathrm{TiCl}_{4}, \mathrm{HCl}$ and $\mathrm{H}_{2} \mathrm{O}_{2}$ resulted in the formation of $\mathrm{TiO}_{2}$ with predominantly rutile microstructure according to the XRD data. ${ }^{90}$ This route is based on the green chemistry principles and the curing is performed at low temperature, up to $100{ }^{\circ} \mathrm{C}$. The sol-gel $\mathrm{TiO}_{2}$ coatings were highly protective with resistance values in the $\mathrm{M} \Omega$ $\mathrm{cm}^{2}$ range, as confirmed by polarization and electrochemical impedance measurements. ${ }^{90}$ Furthermore, this type of sol-gel is suitable for further functionalization in terms of antibacterial ability. Silver is known for its inherent antibacterial activity against different microorganisms. ${ }^{92}$ Silver(I) nitrate was added to $\mathrm{TiO}_{2}$ sol which resulted in the incorporation of silver nanoparticles in the coating structure. ${ }^{90}$ Once $\mathrm{TiO}_{2}-\mathrm{Ag}$ coating was exposed to bacteria, the adhesion of $P$. aeruginosa was reduced and bacteria shape destroyed.

Instead using $\mathrm{Ag}$ nanoparticles to $\mathrm{TiO}_{2}$ sol-gel matrix, we can add $\mathrm{TiO}_{2}$ particles to inorganic-epoxy-based matrix. Illuminated $\mathrm{TiO}_{2}$ has the ability of photo-killing of bacteria by photocatalytic action which proceeds in three stages: disordering of outer membrane of bacteria cell by reactive species $\left({ }^{\circ} \mathrm{OH}, \mathrm{H}_{2} \mathrm{O}_{2},{ }^{\cdot} \mathrm{O}_{2}^{-}\right)$, disordering of the inner membrane (cytoplasmic) and killing the cell, and decomposition of the dead cell. ${ }^{92}$ Epoxy-based precursor GPTMS was used in combination with zirconium-based inorganic precursor ZTP and acetic acid as catalyst (coating denoted as ZG). ${ }^{89}$ The final sol contains $\mathrm{Zr}-\mathrm{O}-\mathrm{Zr}$, Si$\mathrm{O}-\mathrm{Si}$ and $\mathrm{Zr}-\mathrm{O}-\mathrm{Si}$ bonds and incorporates acetate in its structure in a bidentate chelate coordination After deposition of the sol in the form of a coating on titanium substrate and curing at $150^{\circ} \mathrm{C}$ the opening of the epoxy ring at GPTMS leads to complete polymerization of the organic network and formation of a dense and homogeneous coating suitable for biomedical application. ${ }^{89}$ After addition of
$\mathrm{TiO}_{2}$ nanoparticles to sol and their incorporation in the coating, the antibacterial activity was gained. Survival of bacteria St. aureus on Ti coated by ZG coating with addition of $\mathrm{TiO}_{2}$ nanoparticles decreased 5-fold compared to untreated $\mathrm{Ti}^{93}$

Osseointegration is another property important in biomedical applications. Biomimetic materials such as hydroxyapatite coatings, with a structure close to the bone matrix, have been introduced and widely investigated. Fluorohydroxyapatite (FHA) and fluoroapatite (FA) were deposited aiming to substitute of $\mathrm{F}^{-}$for $\mathrm{OH}^{-}$in order to lower the solubility of apatite, since high solubility could weaken the bond between implant and newly grown bone. ${ }^{91}$ Total substitution with FA would not be a good solution since it is too stable and appears to be non-osteoconductive. The initial triethyl phosphite precursor was hydrolyzed to phosphate after the addition of ammonium fluoride and calcium nitrate. Depending on the amount of ammonium fluoride added, FA or FHA sol gels resulted. ${ }^{91}$ The consistency of FA was denser than that of FHA, much richer in small particles and contained larger fluoride content. The coatings exhibit the hydrophilic behavior that is recommended for osteoblast differentiation in tissue engineering and, consequently, for osseointegration.

\section{Hydrophobic and Superhydrophobic Coatings}

Wettability of the surface may affect different properties of the metal or coated metal..$^{94}$ The contact angle $(\theta)$ is the angle, conventionally measured through the liquid, where a liquid-vapor interface meets a solid surface (Fig. 16).
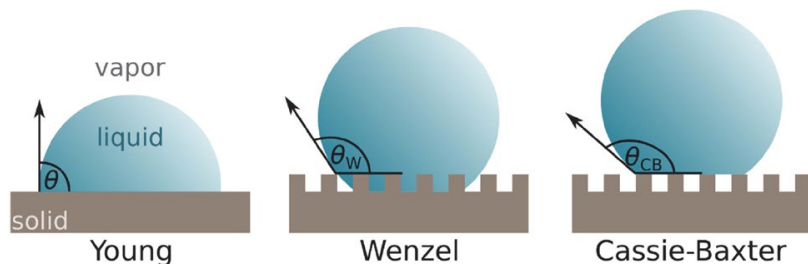

Figure 16. Schematic presentation of different wetting models: Young model on flat surface, and Wenzel and Cassie-Baxter models on rough surfaces. $\theta$ is contact angle of liquid drop.

Contact angle quantifies the wettability of a solid surface by a liquid via the Young equation:

$$
\cos \theta=\frac{\gamma_{s v}-\gamma_{s l}}{\gamma_{l v}}
$$

where $\gamma$ is surface tension ( $\gamma_{\mathrm{sv}}$ is sold-vapour, $\gamma_{\mathrm{sl}}$ is solid-liquid and $\gamma_{\mathrm{lv}}$ is liquid-vapour). Young's equation is valid for ideal flat surfaces. On rough surfaces, the Wenzel regime is usually recognized as homogeneous wetting, since the liquid completely penetrates into the grooves 


$$
\cos \theta_{W}=r \cos \theta
$$

where $\theta_{\mathrm{w}}$ is Wenzel's contact angle and $r$ is roughness parameter. While under some circumstances, especially the increase of the surface roughness, vapour pockets may be trapped underneath the liquid yielding a composite interface. This heterogeneous wetting is usually described by the Cassie-Baxter:

$$
\cos \theta_{C B}=f_{1} \cos \theta_{1}+f_{2} \cos \theta_{2}
$$

where $\theta_{\mathrm{CB}}$ is Cassie-Baxter contact angle, $f_{\mathrm{i}}$ is the fraction of surface area with contact angle $\theta_{\mathrm{i}}\left(\mathrm{f}_{1}+\mathrm{f}_{2}=1\right)$. It can be assumed that liquid is in contact with the solid only at the roughness tips. Due to the presence of air in pockets between rough protrusion, majority of solid surface is not wetted.

In general, superhydrophilic surface has contact angle of liquid drop $\theta<10^{\circ}$, hydrophilic surface has $10^{\circ}<\theta<$ $90^{\circ}$, and hydrophobic $90^{\circ}<\theta<150^{\circ}$. Superhydrophobic surfaces, i.e. those which have a tendency to repel water drops, are characterized by a high apparent contact angle, $\left(\theta>150^{\circ}\right)$, low contact angle hysteresis $\left(<10^{\circ}\right)$, and low sliding angle $\left(\alpha<5^{\circ}\right) .{ }^{94}$ The interest in superhydrophobic surfaces has been rising considerably as reflected by numerous review papers published in the last decade, see for example. ${ }^{95,96}$ Superhydrophobic materials are useful in various industrial and every-day applications, for example as water repellent surfaces, anti-icing, self-cleaning, anti-fogging, anti-fouling, etc. Superhydrophobicity of the surface is achieved by an appropriate combination of surface roughness, texture, and low surface energy. ${ }^{97}$

a)
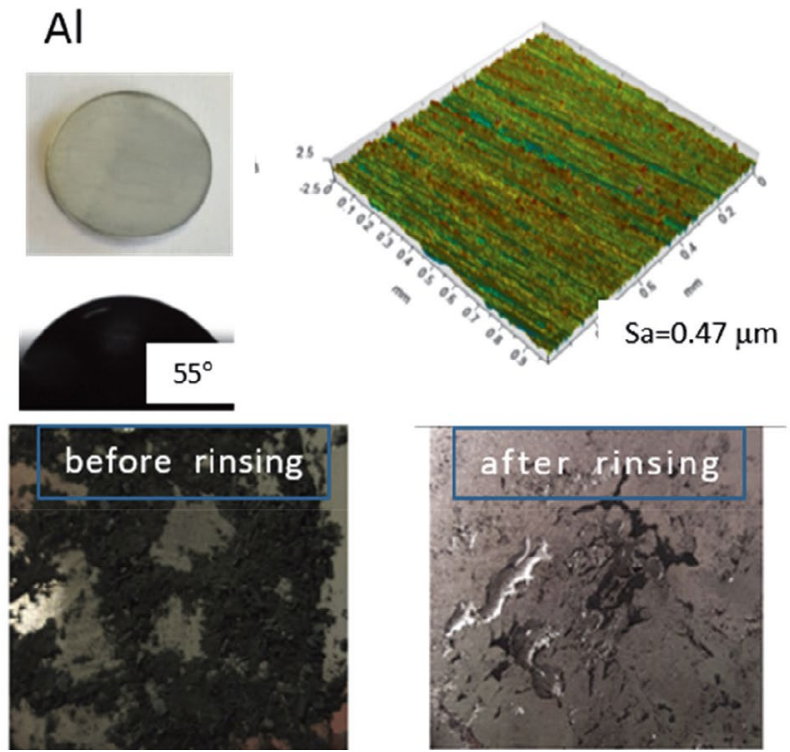

To produce a superhydrophobic surface usually a two-step process is used. The first step is a mechanical modification, i.e. extensive roughening of the surface under alkaline or acid etching aiming to produce protrusions at the surface which would allow the formation of CB regime. The second step is the chemical modification, i.e. coverage of the rough surface by compound of a low surface energy. These compounds usually include long chain alkyl-, silane- or fluorinated compounds. As these chemicals are slightly soluble in water, the immersion is usually carried out in their ethanol solution.

An example is given for production of superhydrophobic aluminium. After grinding on $\mathrm{SiC}$ papers the surface of aluminium has an average roughness of $0.47 \mu \mathrm{m}$ (Fig. 17a). ${ }^{98}$ This surface is hydrophilic, with $\theta=55^{\circ}$. In order to increase the roughness, the surface was etched in solution of iron(III) chloride. This process increased the roughness to $15.7 \mu \mathrm{m}$ (Fig. 17b). After immersion in ethanol solution of fluoroalkly silane (FAS) perfluorodecyl triethoxysilane the surface became superhydrophobic with $\theta$ $=155^{\circ}$ (Fig. 17b). Fluorosilane is adsorbed on metal surface via siloxane $\mathrm{Si}-\mathrm{O}-\mathrm{Si}$ bonds which are formed between hydroxyl group at the metal surface and $\mathrm{Si}-\mathrm{O}$ bonds of silane compound. ${ }^{99}$ Perfluoro chain of FAS bonds via silyl $\mathrm{Si}-\mathrm{C}$ bonds and accounts for hydrophobic character of the formed layer. Such hydrophobic surface acts as a corrosion barrier as it prevents the ingress of aggressive chloride anions to reach the aluminium substrate thereby promoting its dissolution. Furthermore, superhydrophobic surface exhibits the self-cleaning ability. Due to large water contact angle and small sliding angle the dirt particle

b)
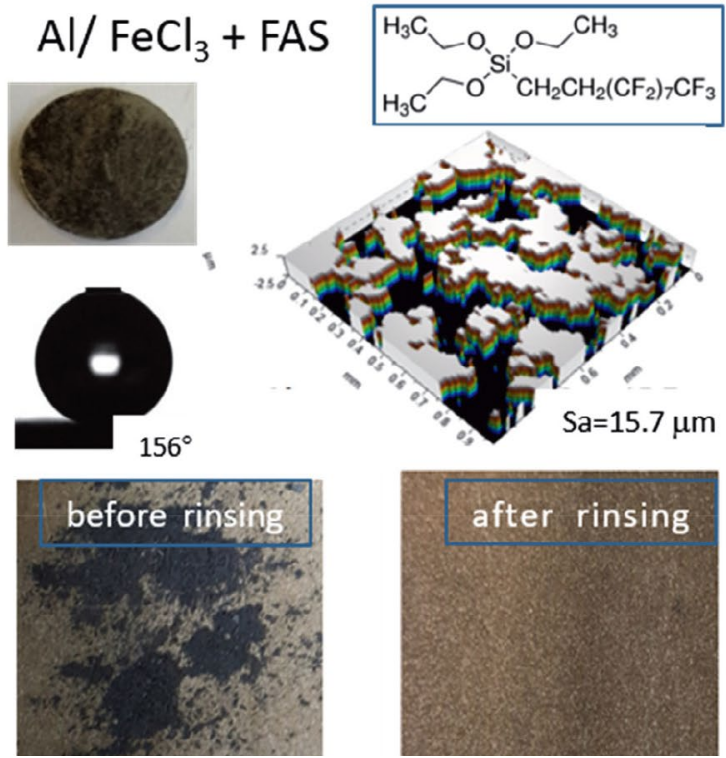

Figure 17. (a) Images of ground aluminium sample, water drop on its surface (contact angle 55 $5^{\circ}, 3$-D topographical profile (mean surface roughness $S_{\mathrm{a}} 0.47 \mu \mathrm{m}$ ) and images of sample covered with carbon particles simulating dirt before and after cleaning with water jet. (b) Images of ground aluminium sample, etched using $\mathrm{FeCl}_{3}$ and immersed in ethanol solution of FAS (perfluorodecyl triethoxysilane), water drop on its surface (contact angle $156^{\circ}$ ), 3-D topographical profile (mean surface roughness $S_{\mathrm{a}} 15.7 \mu \mathrm{m}$ ) and images of sample covered with carbon particles simulating dirt before and after cleaning with water jet. Skeletal formula of FAS is given in (b). ${ }^{98}$ 
can roll-off the surface. This is known as lotus effect. Image in Fig. 17 show the unmodified and FAS-modified Al surface covered with carbon particles simulating dirt. After rinsing with water, the particles remained at the surface of unmodified $\mathrm{Al}$ together with water drop. Because the surface is hydrophilic, the water drop did not roll-off. In contrast, on superhydrophobic surface the same procedure produced a cleaned surface.

\section{Concluding Remarks}

Growing consumption of materials worldwide is putting requirements on materials for increased functionality and versatile physico-chemical properties such as corrosion resistance, thermal barrier, antifouling and antimicrobial properties and mechanical properties such as wear resistance hardness and strength, etc. Let us not forget environmental impact - production of materials should be in line with strict environmental standards. Price of surface treatment is also an important issue governing its marketability. When considering corrosion resistance, it would be desirable for a material to show not only barrier protection but also to respond to triggers from environment, i.e. to recover when damaged. Furthermore, the protective coating should promote subsequent adhesion of topcoat. Corrosion protection is usually a combination of several layers: pre-treatment, followed by primer and toplayer. Therefore, versatility in modes and treatments is desirable. These high requirements and strict environmental and economic rules are setting high demands on industrial producers and, consequently, boosting research studies in industrial and academic sectors aiming for new materials and integrative solutions.

\section{Acknowledgements}

I would like to thank my colleagues at the Department of Physical and Organic Chemistry doc. dr. Anton Kokalj, dr. Antonija Lesar, prof. dr. Jernej Iskra and prof. dr Stojan Stavber for fruitful collaboration. Valuable research work of Ph.D. students and coworkers in last 15 years is acknowledged: dr. Tadeja Kosec, dr. Matjaž Finšgar, dr. Sebastijan Peljhan, dr. Nataša Kovačević, dr. Jasminka Pavlinac, Dunja Gustinčič, M.Chem., dr. Gregor Žerjav, dr. Peter Rodič, dr. Nicoleta Cotolan, dr. Daniela Covaciu Romonți, dr. Urša Tiringer, dr. Barbara Volarič, Gavrilo Šekularac, M.Chem., Barbara Kapun, B.Sc., and dr. Matic Poberžnik. I would like to acknowledge Katja Milošev, M.Arch., for drawing Figures 2 and 3, Dolores Zimerl, M.Chem., for drawing Figure 6 and dr. Matic Poberžnik for drawing Figure 16. The financial support of our research work by the Slovenian Research Agency is greatly appreciated (research core funding No. P2-0393).
List of symbols:

$E$ - electrode potential [V]

$E_{\text {oc }}$ - open circuit potential [V]

$E_{\text {corr }}$ - corrosion potential [V]

$E_{\text {pit }}-$ pitting potential [V]

$\Delta E=\left|E_{\text {corr }}-E_{\text {pit }}\right|-$ pseudo-passive range [V]

$j$ - current density [ $\left.\mathrm{A} \mathrm{cm}^{-2}\right]$

$j_{\text {corr }}-$ corrosion current density $\left[\mathrm{A} \mathrm{cm}^{-2}\right]$

$\theta$ - contact angle $\left[^{\circ}\right]$

$\alpha$ - sliding angle $\left[{ }^{\circ}\right]$

$\gamma$ - surface tension $\left[\mathrm{N} \mathrm{m}^{-1}\right]$

\section{List of abbrevations:}

A - annealed (temper designation for $\mathrm{Cu}$ alloys)

ATR FTIR - attenuated total reflectance Fourier transform infrared spectroscopy

1-ATriH - 1-amino-1,2,4-triazole

3-ATriH - 3-amino-1,2,4-triazole

5-ATriH - 5-amino-1,2,4-triazole

BimH - benzimidazole

BTAH - benzotriazole

BTAOH - 1-hydroxybenzotriazole

CCC - chromate conversion coating

DFT - Density Functional Theory

DLS - dynamic light scattering

ECHA - European Chemical Agency

EDS - energy dispersive X-ray spectrometry

$\mathrm{F}$ - as fabricated (temper designation for Al alloys)

FA - fluoroapatite

FAS - fluoroalkyl silane

FHA - fluorohydroxypatite

GDOES - glow discharge optical emission spectroscopy

GPTMS - 3-glycidoxypropyl-trimethoxysilane

GTS - coating based on GPTMS, TEOS and $\mathrm{SiO}_{2}$

GTS-Ce - coating based on GPTMS, TEOS, $\mathrm{SiO}_{2}$ and $\mathrm{Ce}\left(\mathrm{NO}_{3}\right)_{3}$

$\mathrm{H}$ - strain hardened (temper designation for $\mathrm{Al}$ alloys)

$\mathrm{H}$ - cold-worked (temper designation for $\mathrm{Cu}$ alloys)

ImiH - imidazole

ImiMe - 1-methyl-imidazole

IMP - intermetallic particles

$\mathrm{M}$ - manufactured (temper designation for $\mathrm{Cu}$ alloys)

MAA - methacrylic acid

MAPTMS - 3-methacryloxypropyl trimethoxysilane

MBV - modified Bauer Vogel process

NMR - nuclear magnetic resonance

NTAH - naphthotriazole

$\mathrm{O}$ - annealed (temper designation for $\mathrm{Al}$ alloys)

$\mathrm{Q}$ - quench-hardened (temper designation for $\mathrm{Cu}$ alloys)

REACH - Registration, Evaluation, Authorization and Restriction of Chemicals

ROHS - Restriction of Hazardous Substances

SEM - scanning electron microscopy

SH-BimH - 2-mercaptobenzimidazole 
SH-BimMe - 2-mercapto-1-methylbenzimidazole SVCH - Substances of Very High Concern

$\mathrm{T}$ - thermally treated (temper designation for $\mathrm{Al}$ alloys)

$\mathrm{T}$ - heat-treated (temper designation for $\mathrm{Cu}$ alloys)

TAH - 1,2,3-triazole

TEM - transmission electron microscopy

TEOS - tetraethyl orthosilicate

TGA - thermogravimetric analysis

TMZ - coating based on TEOS, MAPTMS and ZTP

ToF-SIMS - time-of-flight secondary ions mass spectrometry

TriH - 1,2,4-triazole

TriMe - 1-methyl-1,2,4-triazole

UV-vis-NIR - ultraviolet-visible near infrared

$\mathrm{W}$ - solution heat-treated (temper designation for $\mathrm{Al}$ alloys)

XPS - X-ray photoelectron spectroscpy

XRD - X-ray diffraction

ZG - coating based on Zirconium(IV) propoxide and GPTMS

ZTP - zirconium(IV) propoxide

\section{Author biography}

Prof. Ingrid Milošev received her BSc degree at the Faculty of Technology University of Zagreb and PhD degree at the Faculty of Natural Sciences University of Ljubljana. She has been employed at the Jožef Stefan Institute (JSI) since 1987. Since 2001 she holds additional position as a research fellow at the Valdoltra Orthopaedic Hospital. She was a post-doctoral fellow at the Heinrich-Heine University of Düsseldorf, Germany. Since 2005 she has been the head of the Department of Physical and Organic Chemistry at the JSI and since 2013 full professor at the Jožef Stefan International Postgraduate School (JSIPS). From 2007 to 2019 she was the member of the Scientific Council of the JSI, she is currently the member of the Scientific Council of the JSIPS. She has been involved as a project leader or a co-worker in numerous national and European projects such as M-Era.Net, MSC ITN, COST, Interreg, etc.

Dr. Milošev's scientific interests include corrosion processes and corrosion protection of technological and biomedical materials aiming to prolong their life-time and functional abilities. Methodologies of corrosion protection are versatile from sol-gel and conversion coatings, inorganic coatings, self-assembled layers to corrosion inhibitors.

She has published over 170 scientific papers in peer-reviewed journals, presented over 130 contributions at international and national symposia, delivered 14 invited lectures, including the prestigious Gordon conference in USA in 2016, and wrote 6 chapters in scientific books published by international publishing houses. Her publications were cited more than 4500 times (hirsch index 38). Dr. Milošev supervised 8 and co-supervised 3 doctoral
(PhD) theses. She was the guest-editor in Acta Chimica Slovenica (2014), Croatica Chimica Acta (2017) and Corrosion (2017) journals. In last few years she has been awarded outstanding reviewer status in several eminent journals. Since 2016 she has been the associate editor of the journal npj Materials Degradation within the Nature Journal Group.

In 2011 Dr. Milošev was awarded the Slovenian national award - Zois Certificate of Recognition for significant achievements, and in 2016 Pregl award of the National Institute of Chemistry for exceptional achievements.

\section{References}

1. Uhlig's Corrosion Handbook, edited by R. Winston Revie, Second edition, Electrochemical Society Series, Wiley-Interscience, 2006.

2. D. Pletcher, F.C. Walsh, Industrial Electrochemistry, Chapman and Hall, 1990.

3. https://corrosion-doctors.org/Forms/Accidents.htm

4. G. Schmitt, M. Schütze, G.F. Hays, W. Burns, E.-H. Han, A. Pourbaix, G. Jacobson: White paper Global Need for Knowledge Dissemination, Research, and Development in Mateirals Deteriaoration and Corrosion Control, The World Corrosion Organization, 2009 http://corrosion.org/Corrosion+ Resources/Publications/_/whitepaper.pdf

5. B. Hou, X. Li, X. Ma, C. Du, D. Zhang, M. Zhen, W. Xu, D. Lu, F. Ma, npj Materials Degradation 2017, 1, 4:

DOI:10.1038/s41529-017-0005.

6. O. Vidal, B. Goffé, N. Arndt, Nature Geosci. 2013, 6, 894896. DOI:10.1038/s41529-017-0005-2

7. http://www.mining.com/global-energy-transition-powerssurge-demand-metals/

8. https://www.aluminium-messe.com/en/ALUMINIUM-2020 /Demand-for-aluminium-is-growing-worldwide/758/

9. B.W. Schipper, H.-C. Lin, M.A. Meloni, K. Wansleeben, R. Heijungs, E. van der Voet, Resources, Conservation \& Recycling, 2018, 132,28-36. DOI:10.1016/j.resconrec.2018.01.004

10. A. Elshkaki. T.E. Graedel, L. Ciacci, B.K. Reck, Global Environ. Change 2016, 29, 305-315.

DOI:10.1016/j.gloenvcha.2016.06.006

11. https://www.statista.com/statistics/254839/copper-produc tion-by-country/

12. https://copperalliance.eu/about-copper/copper-and-its-alloys /properties/

13. ASTM B 601-02, Standard Classification for Temper Designation for Copper and Copper Alloys-Wrought and Cast.

14. https://ycharts.com

15. http://www.fabricatingandmetalworking.com

16. G. Šekularac, I. Milošev, Corros. Sci. 2018, 144, 54-73. DOI:10.1016/j.corsci.2018.08.038

17. J. R. Davis. Corrosion of Aluminum and Aluminum Alloys, p. 327, ASM International, (1999).

18. https://www.copper.org/resources/properties/protection/ clear_finishes.html. 
19. O. Gharbi, S. Thomas, C. Smith, N. Birbilis, npj Mater. Degrad. 2018, 2, article no. 12, 1-8.

DOI:10.1038/s41529-018-0034-5

20. Z. Gao, D. Zhang, X. Li, S. Jiang, Q. Zhang, Colloids Surf. A 2018, 546, 221-236. DOI:10.1016/j.colsurfa.2018.03.018

21. I. Milošev, G.S. Frankel, J. Electrochem. Soc. 2018, 165, C1C18. DOI:10.1149/2.0371803jes

22. S.T. Abrahami, J.M.M. de Kok, H. Terryn, J.M.C. Mol, Front. Chem. Sci. Eng. 2017, 11, 465-482.

DOI:10.1007/s11705-017-1641-3

23. https://www.european-aluminium.eu/

24. O. Bauer, O. Vogel, German Patent Specification, U.S. Patent no. 423758 .

25. M.W. Kendig, R.G. Buchheit, Corrosion 2003, 59, 379-400. DOI:10.5006/1.3277570

26. J. K. Hawkins, H. S. Isaacs, S. M. Heald, J. Tranquada, G.E. Thompson, G.C. Wood, Corros. Sci.1987, 27, 391-399.

DOI:10.1016/0010-938X(87)90081-3

27. J. Zhao, G.S. Frankel, R.L. McCreery, J. Electrochem. Soc. 1998, 145, 2258-2264. DOI:10.1149/1.1838630

28. S. Adhikari, K.A. Unocic, Y. Zhai, G.S. Frankel, J. Zimmerman, Electrochim. Acta 2011, 56, 1912-1924.

DOI:10.1016/j.electacta.2010.07.037

29. https://www.rohsguide.com/

30. https://www.osha.gov/

31. https://echa.europa.eu/

32. http://europa.eu/rapid/press-release_IP-10-1465_en.htm

33. D.J. Gardiner, A.C. Gorvin, C. Gutteridge, A.R. Jackson, E.S. Raper, Corros. Sci. 1985, 25, 1019-1027. DOI:10.1016/0010-938X(85)90069-1

34. C. Deslouis, B. Tribollet, G. Mengoli, M. Musiani, J. Appl. Electrochem. 1988, 18, 374-383. DOI:10.1007/BF01093751

35. G. Kear, B. D. Barker, F. C. Walsh, Corros. Sci. 2004, 46, 109135. DOI:10.1016/S0010-938X(02)00257-3

36. I. Milošev, M. Metikoš-Huković, J. Electrochem. Soc. 1991, $138,61-67$.

37. T. Kosec, I. Milošev, B. Pihlar, Appl. Surf. Sci. 2007, 253, 8863-8873. DOI:10.1016/j.apsusc.2007.04.083

38. T. Kosec, D. Kek Merl, I. Milošev, Corros. Sci. 2008, 50, 19871997. DOI:10.1016/j.corsci.2008.04.016

39. M. Finšgar, A. Lesar, A. Kokalj, I. Milošev, Electrochim. Acta 2008, 53, 8287-8297. DOI:10.1016/j.electacta.2008.06.061

40. M. Finšgar, I. Milošev, Corros. Sci. 2010, 52, 2737-2749. DOI:10.1016/j.corsci.2010.05.002

41. D. Tromans, R.-H. Sun, J. Electrochem. Soc. 138 (1991) 32353244. DOI:10.1149/1.2085397

42. A. Kokalj, S. Peljhan, M. Finšgar, I. Milošev, J. Am. Chem. Soc. 2010, 132, 16657-16668. DOI:10.1021/ja107704y

43. M. Finšgar, J. Kovač, I. Milošev, J. Electrochem. Soc. 2010, 157, C52-C60. DOI:10.1016/j.corsci.2010.04.001

44. M. Finšgar, I. Milošev, Mater. Corr. 2011, 62, 956-966. DOI:10.1002/maco.201005645

45. A. Lesar, I. Milošev, Chem. Phys. Lett.. 2009, 483, 198-203. DOI:10.1016/j.cplett.2009.10.082

46. M. Finšgar, I. Milošev, B. Pihlar, Acta Chim. Slov. 2007, 54, 591-597.
47. A. Kokalj, N. Kovačević, S. Peljhan, M. Finšgar, A. Lesar, I. Milošev, ChemPhysChem 2011, 12, 3547-3555.

DOI:10.1002/cphc.201100537

48. I. Milošev, N. Kovačević, A. Kokalj, Corros. Sci. 2015, 98, 107-118. DOI:10.1016/j.corsci.2015.05.006

49. N. Kovačević, I. Milošev, A. Kokalj, Corros. Sci. 2015, 98, 457-470. DOI:10.1016/j.corsci.2015.05.041

50. N. Kovačević, I. Milošev, A. Kokalj, Corros. Sci. 2017, 124, 25-34. DOI:10.1016/j.corsci.2017.04.021

51. I. Milošev, N. Kovačević, A. Kokalj, Acta Chim. Slov. 2016, 63, 544-559. DOI:10.17344/acsi.2016.2326

52. A. Kokalj, Molecular Modeling of Corrosion Inhibitors, In: Reference Module in Chemistry, Molecular Sciences and Chemical Engineering, Elsevier, vol. 61, 2018, pp. 332-345. DOI:10.1016/B978-0-12-409547-2.13444-4

53. D. Peca, B. Pihlar, Milošev, Acta Chim. Slov. 2014, 61, 457467.

54. I. Milošev, J. Pavlinac, M. Hodošček, A. Lesar, J. Serb. Chem. Soc. 2013, 78, 2069-2086. DOI:10.2298/JSC131126146M

55. I. Milošev, T. Kosec, M. Bele, J. Appl. Electrochem. 2010, 40, 1317-1323. DOI:10.1007/s10800-010-0078-x

56. T. Kosec, A. Legat, I. Milošev, Prog. Org. Coat. 2010, 69, 199206. DOI:10.1016/j.porgcoat.2010.04.010

57. G. Žerjav, I. Milošev, Corros. Sci. 2015, 98, 180-191. DOI:10.1016/j.corsci.2015.05.023

58. G. Žerjav, I. Milošev, Int. J. Electrochem. Soc. 2014, 9, 26962715.

59. G. Žerjav, I. Milošev, Mater. Corr. 2015, 66, 1402-1413. DOI:10.1002/maco.201508383

60. G. Žerjav, I. Milošev, Mater. Corr. 2016, 67, 92-103 DOI:10.1002/maco.201508384

61. G. Žerjav, A. Lanzutti, F. Andreatta, L. Fedrizzi, I. Milošev, Mater. Corr. 2017, 68, 30-41. DOI:10.1002/maco.201608954

62. B.R.W. Hinton, D.R. Arnott, N.E. Ryan, Met. Forum 1985, 7, 211-217.

63. T. G. Harvey, Corr. Eng. Sci. Technol. 2013, 48, 248-269. DOI:10.1179/1743278213Y.0000000089

64. K.A. Yasakau, M.L. Zheludkevich, S,V. Lamaka, M.G.S. Ferreira, J. Phys. Chem. B 2006, 110, 5515-5528.

DOI:10.1021/jp0560664

65. F.H. Scholes, C. Soste, A.E. Hughes, S.G. Hardin, P.R. Curtis, Appl. Surf. Sci. 2006, 253, 1770-1780.

DOI:10.1016/j.apsusc.2006.03.010

66. P. Rodič, I. Milošev, J. Electrochem. Soc. 2016, 163, C85-C93. DOI:10.1149/2.0431603jes

67. I. Milošev, P. Rodič, Corrosion 2016, 72, 1021-1034.

68. I. Santana, A. Pepe, E. Jimenez-Pique, S. Pellice, I. Milošev, S. Ceré, Surf. Coat. Technol. 2015, 265, 106-115.

DOI:10.1016/j.surfcoat.2015.01.050

69. B. Volarič, I. Milošev, Corr. Eng. Sci. Technol. 2017, 52, 201211. DOI:10.1080/1478422X.2016.1245957

70. I. Milošev, B. Volarič, Corrosion 2017, 73, 822-843. DOI:10.5006/2353

71. B. Volarič, A. Manzare, S. Virtanen, I. Milošev, to be submitted.

72. Y. Gonzales-Garcia, S.J. Garcia, J.M.C. Mol, Chapter 9, In: 
Active Protective Coatings, edited by A.E. Hughes, J.M.C. Mol, M.L. Zheludkevich, R.G. Buchheit, Springer Series in Materials Science, vol. 233, 2016, pp. 203-240.

73. P. Rodič, I. Milošev, Corros. Sci. 2019, 149, 108-122. DOI:10.1016/j.corsci.2018.10.021

74. R.B. Figueira, C.J.R. Silva, E.V. Pereira, J. Coat. Technol. Res. 2015, 12, 1-35. DOI:10.1007/s11998-014-9595-6

75. A.C. Pierre, Introduction to Sol-Gel Processing, Springer US, 1998. DOI: $10.1007 / 978-1-4615-5659-6$

76. I. Milošev, Ž. Jovanović, J.B. Bajat, R. Jančić-Heinemann, V.B. Mišković-Stanković, J. Electrochem. Soc. 2012, 159, C303C311. DOI:10.1149/2.042207jes

77. P. Rodič, J. Iskra, I. Milošev, J. Sol-Gel Sci. Technol. 2014, 70, 90-103. DOI:10.1007/s10971-014-3278-8

78. P. Rodič, J. Iskra, I. Milošev, J. Non-Cryst. Solids 2014, 396397, 25-35. DOI:10.1016/j.jnoncrysol.2014.04.013

79. P. Rodič, A. Mertelj, M. Borovšak, A. Benčan, D. Mihailović, B. Malič, I. Milošev, Surf. Coat. Technol. 2016, 286, 388-396. DOI:10.1016/j.surfcoat.2015.12.036

80. P. Rodič, I. Milošev, J. Electrochem. Soc. 2014, 161, C412C420. DOI:10.1149/2.1091409jes

81. P. Rodič, I. Milošev, M. Lekka, F. Andreatta, L. Fedrizzi, Prog. Org. Coat. 2018, 124, 286-295.

DOI:10.1016/j.porgcoat.2018.02.025

82. U. Tiringer, I. Milošev, A. Durán, Y. Castro, J. Sol-Gel Sci. Technol. 2018, 85, 546-557.

DOI:10.1007/s10971-017-4577-7

83. U. Tiringer, B. Mušič, D. Zimerl, G. Šekularac, S. Stavber, I. Milošev, J. Non-Cryst. Solids 2019, 510, 93-100.

DOI:10.1016/j.jnoncrysol.2018.12.021

84. U. Tiringer, J. Kovač, I. Milošev, Corros. Sci. 2017, 119, 46-59. DOI:10.1016/j.corsci.2017.02.018

85. H.R. Fischer, S.J. Garcia, Chapter 7, In: Active Protective Coatings, edited by A.E. Hughes, J.M.C. Mol, M.L. Zheludkevich, R.G. Buchheit, Springer Series in Materials Science, vol. 233, 2016, pp. 139-156.

86. P. Rodič, J. Katić, D. Korte, P.M. Desimone, M. Franko, S.M. Ceré, M. Metikoš-Huković, I. Milošev, Metals 2018, 8, met8040248. DOI:10.3390/met8040248
87. U. Tiringer, A. Durán, Y. Castro, I. Milošev, J. Electrochem. Soc. 2018, 165, C1-C13.

88. I. Milošev, Pure \& Appl. Chem. 2011, 83, 309-324. DOI:10.1351/PAC-CON-10-07-09

89. I. Milošev, B. Kapun, P. Rodič, J. Iskra, J. Sol-Gel Sci. Technol. 2015, 74, 447-459. DOI:10.1007/s10971-015-3620-9

90. N. Cotolan, M. Rak, M. Bele, A. Cör, L.M. Muresan, I. Milošev, Surf. Coat. Technol. 2016, 307, 790-799.

DOI:10.1016/j.surfcoat.2016.09.082

91. D. Covaciu Romonți, J. Iskra, M. Bele, I. Demetrescu, I. Milošev, J. Alloys Compd. 2016, 665, 355-364.

DOI:10.1016/j.jallcom.2016.01.072

92. I. Milošev, In: Biomedical and Pharmaceutical Applications of Electrochemistry, edited by S. Djokić, Modern Aspects of Electrochemistry, vol. 60, Springer, 2016, pp. 1-88.

93. B. Kapun, J. Iskra, P. Rodič, M. Bele, N. Veronovski, F. Šulek, M. Rak, A. Cör, I. Milošev, In: Book of Abstracts, edited by Z. Kravanja, D. Brodnik-Vončina, M. Bogataj, Slovenski kemijski dnevi 2012, Portorož, 12.-14. 9. 2012. p. 49.

DOI:10.1007/s15200-012-0649-5

94. N.J. Shirtcliffe, G. McHale, S. Atherton, and M.I. Newton, Adv. Colloid Interface Sci., 2010, 161, 124-138.

DOI:10.1016/j.cis.2009.11.001

95. S. Das, S. Kumar, S.K. Samal, S. Mohanty, and S.K. Nayak, Ind. Eng. Chem. Res. 2018, 57, 2727-2745.

96. J. Jeevahan, M. Chandrasekaran, G. Britto Joseph, R.B. Durairaj, and G. Mageshwaran, J. Coat. Res. Technol., 2018, 15, 231-250. DOI:10.1021/acs.iecr.7b04887

DOI:10.1007/s11998-017-0011-x

97. I. Milošev, T. Bakarič, S. Zanna, A. Seyeux, P. Rodič, M. Poberžnik, F. Chiter, P. Cornette, D. Costa, A. Kokalj, P. Marcus, J. Electrochem. Soc. 2019, 166, C1-C16.

DOI:10.1149/2.0181911jes

98. S. Iskra, P. Rodič, I. Milošev, J. Pust, golden award at the 50th Meeting of young researchers of Slovenia 2016, Zavod za tehnično kulturo Slovenije.

99. P. Rodič, I. Milošev, Surf. Coat. Technol. 2019, 368, 175-185. DOI:10.1016/j.surfcoat.2019.03.082

\section{Povzetek}

Zaščita pred korozijo je pomembno globalno vprašanje. Korozija vpliva na vse kovinske materiale v industriji, infrastrukturi, gradbeništvu, prometu, biomedicini, itn., kar povzroča njihov propad. Zato je zaščita pred korozijo nujnost, ki omogoča varno in dobro delovanje kovinskih konstrukcij in naprav. Poleg dolgoročne učinkovitosti mora biti zaščita pred korozijo okoljsko in ekonomsko sprejemljiva. Rastoča populacija s potrebami po modernih in visokotehnoloških tehnologijah povečuje porabo osnovnih in redkih kovin. Vsa ta dejstva postavljajo na področje korozijske zaščite visoke zahteve, katerih glavni cilj je podaljšati življenjsko dobo kovinskih materialov, zmanjšati potrebo po strmo naraščajoči proizvodnji in s tem ohraniti naravne vire. V tem preglednem članku so predstavljeni sodobni načini korozijske zaščite materialov, zlasti bakrovih in aluminijih zlitin kot enih najpomembnejših osnovnih kovin. Ti načini zaščite vključujejo inhibitorje korozije, konverzijske, sol-gel in hidrofobne prevleke. Podani so primeri naših raziskav v zadnjem desetletju.

Except when otherwise noted, articles in this journal are published under the terms and conditions of the Creative Commons Attribution 4.0 International License 